\title{
A Neoarchean Paleomagnetic Pole from the Kisii Series of Western Kenya: Implications for Crustal Mobility
}

\author{
Joseph G. Meert ${ }^{1}$, Rob Van der Voo ${ }^{2}$ and Jayanti Patel ${ }^{3}$ \\ 1Department of Geological Sciences, 355 Williamson Hall, University of Florida, Gainesville, \\ FL 32611 \\ ${ }^{2}$ Department of Earth and Environmental Sciences, 2534 C.C. Little Bldg. University of \\ Michigan, Ann Arbor, MI 48109 \\ ${ }^{3}$ Department of Physics, University of Nairobi, Nairobi, Kenya
}

\section{Abstract}

The Kisii Series lavas of western Kenya were the target of a paleomagnetic study. The Kisii Series is a volcano-sedimentary sequence dated to $2531 \pm 3 \mathrm{Ma}(\mathrm{U}-\mathrm{Pb})$ that rests unconformably over the Mesoarchean-Neoarchean Nyanzian and Kavirondian Series. The paleomagnetic study reported in this paper expands on an earlier study by Brock et al. (1972) using modern demagnetization and analysis techniques. In spite of the advanced methods, the results of both our new study and the previous study are statistically indistinguishable. We therefore combine the results of both investigations to arrive at a grand mean pole at $7^{\circ} \mathrm{S}, 166^{\circ} \mathrm{E}\left(\mathrm{A} 95=8^{\circ}\right)$. Due to the relatively minor tilt-corrections, a fold test is inconclusive; however, the dual-polarity magnetization passes a reversal test. We argue for a primary remanence on the basis of a comparison to other paleomagnetic data in Kenya and Tanzania and geological information. We examine the relationships between age-equivalent paleomagnetic poles from the Tanzanian, Zimbabwe and Kaapvaal cratons. Based on this limited dataset, we cannot conclude whether or not the observed apparent polar wander was due to true polar wander or modern-style plate tectonics, such as would be implied by the (variable) apparent polar wander path segments. We favor the latter explanation based on the disparate lengths of the Zimbabwe versus Tanzanian apparent polar wander paths during the 2700-2500 Ma interval. The Protopangea model is not consistent with paleomagnetic data from these three cratons.

Keywords: Neoarchean, paleomagnetism, plate tectonics, Protopangea

(C) 2016. This manuscript version is made available under the Elsevier user license

http://www.elsevier.com/open-access/userlicense/1.0/ 


\section{Introduction}

Debates regarding the onset of modern-style tectonics during the Precambrian have blossomed in the past two decades (Piper, 2013; Condie and Kroner, 2008; Condie and Pease, 2008, Davies, 1992; Stern, 2008; Evans and Pisarevsky, 2008; Cawood et al., 2006). At the extreme ends of the argument are those who advocate modern-style plate tectonics from Archean to present (Bercovici and Ricard, 2014; Shirey and Richardson, 2011; Cawood et al., 2006) and those who argue that modern style plate tectonics did not begin until 1000-1100 Ma or perhaps slightly later in the Neoproterozoic (Moores, 1993; Stern, 2005, 2008; Hamilton, 2011; Piper, 2013). Still others advocate a transition from lid-style tectonism to a subduction driven system (Piper, 2013; Moore and Webb, 2013). Many of the arguments are based on thermal models and the evolution of mantle-crust rheology (Bercovici and Ricard, 2014; Korenaga, 2013; Moore and Webb, 2013; Shirey and Richardson, 2011).

Paleomagnetic studies allow for a quantitative assessment of horizontal motion and the relationships between different crustal elements (Evans and Pisarevsky, 2008; Piper, 2010, 2013), but treatment of the data are highly variable in these studies. As an example, Piper (2010) uses a minimal quality filter (i.e. stepwise demagnetization, $A 95<16^{\circ}$, magnetization interpreted to be primary and rock ages known to within $\pm 200 \mathrm{Ma}$ ). It appears that the last criterion (loose age constraints) provides the foundation for Piper's argument favoring long-lived crustal integrity of Protopangea (see discussion in Meert, 2014; Meert and Torsvik, 2003, 2004). In contrast, Evans and Pisarevsky (2008) apply very rigid criteria using only 'key' poles (Buchan et al., 2000). Unfortunately, applying either a highly restrictive or a generously permissive filter to the data results in ambiguous conclusions. Evans and Pisarevsky (2008) conclude that there is a single instance of 'platelike' motion during the Archean that can be separated from true polar wander. In contrast, Piper (2010) concludes that the Archean and Paleoproterozoic intervals were dominated by 'stagnant-lid' tectonics where the main crustal blocks remained in a semi-rigid configuration. In the Piper (2010) model, the bulk of motion resulted from inertial instabilities leading to true polar wander or, alternatively, motion of the single 
"Protopangean" lid over the mantle. Piper (2010) argues that modern-style plate tectonics did not begin until the Neoproterozoic.

Paleomagnetic studies on Archean-age rocks may provide quantitative evidence for mobility of the crust; although the studies are often fraught with difficulties. Many of the sequences were deformed and metamorphosed such that the magnetism has been reset to a younger time. In other cases, the paleomagnetic directions are well constrained, but the age of the unit is not known. The Kisii Series in Kenya (figure 1) is a relatively undeformed and unmetamorphosed volcano-sedimentary sequence. In this paper, we update the results of Brock et al. (1972) who used mainly blanket Af-demagnetization techniques on the Kisii lavas of western Kenya. We also discuss the implications of our results for the Protopangea model and Archean crustal mobility.

\section{Geology and Tectonics of the Kisii Region}

Kabete et al. (2012a,b) summarized recent geochronological work on the Tanzanian craton, and the ages quoted in this section and figure 2 are from that compilation. The basement rocks of the Tanzanian craton are composed of the Dodoman gneisses and schists ( $>3600$ to $\sim 3100 \mathrm{Ma}$ ). The schists and gneisses are intruded by the so-called 'Older Granites' (3100-2850 Ma) and are unconformably overlain by the Nyanzian System composed of bi-modal volcanic rocks and banded iron formations (2850-2700 Ma). The Nyanzian System is folded, faulted and intruded by granitic rocks. The intrusion of the granitic rocks (2680-2650 Ma) coincides with the major phase of deformation in the Nyanzian rocks (folding and faulting; Kabete et al., 2012a,b; Meert et al. 1994). ${ }^{40} \mathrm{Ar} /{ }^{39} \mathrm{Ar}$ ages from the Nyanzian basalts in the Kisii region yielded plateau ages between 2670-2680 Ma that were interpreted to reflect the age of metamorphism/deformation (Meert et al., 1994). The Nyanzian System is overlain by the Kavirondian Group (conglomerate and associated sedimentary rocks). The Kavirondian Group is locally intruded by granites and is also folded (Negcu and Gaciri, 1995).

Pinna et al. (2000) provide a useful geological summary of the Kisii Series. Initial mapping of the Kisii Series was conducted by the Geological Survey of Kenya (Shackleton, 1948; Schoeman, 1949; Huddleston, 1951; Saggerson, 1952). The sequence lies 
unconformably over older granite, gneisses and rocks of the Kavirondian Group and Nyanzian System (figures 1 and 2). From bottom to top, the Kisii Series is comprised of (a) basalts and porphyritic basalts; (b) arenite and quartzites; (c) Ignimbrites, felsites and rhyolites; (d) upper volcaniclastic beds and andesites. The Kisii Series is intruded by a few younger dolerite dykes of unknown age. Localized deformation includes minor tilting and faulting (most units in this study had dips $<10^{\circ}$ ). The age of the minor tilting in the region is not known, but is most probably related to the development of the East African Rift (Tertiary or younger). There are also localized strike-slip and reverse faults along the eastern margin of the basin that formed during the East African Orogeny (Huddleston, 1951; Pinna et al., 2000).

The lack of penetrative deformation and regional metamorphism led many to correlate the Kisii Series with other cratonic cover sequences in the Tanzanian craton (see summary in Pinna et al., 2000). Huddleston (1951), following the leads of Shackleton (1948) and Schoeman (1949) equated the rocks in the Kisii Quadrangle to the Bukoban Series in Tanzania and Burundi. Geochronological studies on the Bukoban rocks were conducted on the Gagwe and Kabuye lavas in Tanzania and Burundi. These rocks yielded limited, but consistent K-Ar ages between 810-822 Ma (recalculated using modern decay constants; Briden et al., 1971; Cahen and Snelling, 1974, Cahen et al., 1984). Attempts to date the Kisii lavas using K-Ar methods yielded a much wider range of ages between 5461283 Ma (Cahen and Snelling, 1966; Briden et al., 1971; Charlton, 1973; Meert, 1993). The traditional correlation between the Bukoban and Kisii Series was first questioned by Brock et al. (1972) and Brock and Piper (1972). In companion papers, Brock et al. (1972) and Brock and Piper (1972) cited 'reliable' K-Ar ages from the Kisii lavas of 930 Ma published the previous year by Briden et al. (1971) as proof that the Bukoban and Kisii rocks were of significantly different ages. They further showed that paleomagnetic directions from the Bukoban Sequence (including the Gagwe lavas) were distinct from the Kisii lavas pole. The paleomagnetic argument was more compelling than the geochronological evidence, as Charlton (1973) and Meert (1993) showed that the K-Ar system in the Kisii lavas was highly disturbed. Neither study was able to isolate well-defined ${ }^{40} \mathrm{Ar} /{ }^{39} \mathrm{Ar}$ plateaus in whole rock or in mineral separates. Total ${ }^{40} \mathrm{Ar} /{ }^{39} \mathrm{Ar}$ fusion ages in those two studies (i.e. K- 
Ar equivalent ages) ranged from 823 to 1283 Ma. Meert (1993) also attempted to date the Kisii Series using the ${ }^{147} \mathrm{Sm} /{ }^{143} \mathrm{Nd}$ isotopic system on whole-rock/clinopyroxene pairs and obtained widely disparate model ages between 2208 and 3215 Ma.

More recently, zircon data from the upper part of the Kisii lava sequence (Ikonge Ignimbrite) yielded a U-Pb single zircon evaporation age of $2531 \pm 3$ Ma (Pinna et al., 2000). Pinna et al. (2000) concluded that the Kisii Series volcano-sedimentary sequence was produced during Late Archean subduction coinciding with the waning phases of the Victorian Orogeny. There are also now more precise age constraints on the Bukoban volcanic rocks (i.e. Gagwe lavas). Deblond et al. (2001) argued that a $795 \pm 7 \mathrm{Ma}$ $\left({ }^{40} \mathrm{Ar} /{ }^{39} \mathrm{Ar}\right)$ age on Gagwe intrusive equivalents in Burundi was the best estimate for the age of the lavas and that the previously published K-Ar ages suffered from excess argon.

Given the new geochronological data discussed above and the known disparity between the paleomagnetic directions observed in the Kisii Series (Brock et al., 1972, this study) and the Bukoban sequence (Piper, 1972; Meert et al., 1995), the correlation between the two sequences is no longer tenable (Figure 3).

Additional paleomagnetic studies in the region were conducted on granitic rocks that intrude the Kavirondian and Nyanzian rocks (Patel and Raja, 1979; Patel, 1989) and the Nyanzian volcanic rocks (Meert et al., 1994). The paleomagnetic directions obtained from the granites that were intruded prior to folding of the Nyanzian and Kavirondian Systems are no longer considered valid because they are likely to have experienced tilting or rotation (Figure 3; see also Meert et al., 1994).

\section{Methods}

A total of 90 samples were collected from 10 sites in the Kisii lava sequence. Eight of the sites sampled the lower basaltic flows and two sites were taken from the more felsic upper part of the Series (Figure 1). Samples were collected in the field using a gasolinepowered drill and oriented using solar and magnetic compass. All samples were then cut to standard-sized cores and the natural remanent magnetization (NRM) was measured on either a ScT cryogenic or Schonstedt spinner magnetometer at the University of Michigan's paleomagnetic laboratory. Thermal and alternating field (AF) demagnetization was 
carried out on a pilot selection of samples to choose the optimal method of magnetic cleaning. Both methods proved to be equally successful, but the majority of samples were treated thermally because a more complete decay of the NRM could be achieved. Rock magnetic studies included isothermal remanence acquisition (IRM) and Curie temperature analyses. IRM was stepwise induced up to $1.0 \mathrm{~T}$ using an ASC-Scientific pulse magnetizer (ASC Scientific) at the University of Florida. Susceptibility-temperature measurements (Curie runs) were conducted on a KLY-3S bridge with CS-3 furnace under argon-gas (Agico Instruments) at the University of Florida.

\section{Results}

\section{Paleomagnetic Results}

The original study by Brock et al. (1972) used a combination of either stepwise or blanket alternating field demagnetization. Details regarding which sites received full stepwise demagnetization and which samples were blanket-treated was not clarified in their manuscript. Table 1 of Brock et al. (1972) lists peak Af-cleaning fields ranging from $15-40 \mathrm{mT}$.

Of the 90 samples we collected, 71 samples showed easily interpretable results (figures 4a-c, 5a-c, 6a-c and 7a-c). Some samples exhibited near uni-vectorial decay to the origin (figure $4 \mathrm{a}$ ) while others showed one or two lower-temperature overprints ( $<520 \mathrm{C}$; figures $5 \mathrm{a}, 6 \mathrm{a}$ and $7 \mathrm{a})$. The most consistent overprint $\left(<300^{\circ} \mathrm{C}\right)$ was directed to the north and shallowly up (recent field overprint; see figures 5a, 6a for example). The remaining 19 samples yielded only a recent field overprint (north-shallow) or chaotic behavior during demagnetization and are not considered further in the results.

The magnetization directions in our study show dual-polarity magnetizations although the majority of sites (15/17) show upwardly directed inclinations. We performed a reversal test (McFadden and McElhinny, 1990) on the mean directions for each polarity. The in-situ data passes the reversals test with a classification of $\operatorname{Rb}\left(\lambda=5.35^{\circ}, \lambda_{\text {crit }}=15.35^{\circ}\right)$ and the tilt-corrected data pass a reversals test with a classification of $\operatorname{Ra}\left(C \lambda=4.7^{\circ}\right.$, $\lambda_{\text {crit }}=14.82^{\circ}$ ). 
The mean directions for the high-temperature/coercivity components in our study are given in Table 1. Two sites in the more acidic lavas showed directions that were reverse (west-down) as compared to the remaining eight sites in the lavas (east-up). After inverting the directions from the acidic lavas, the mean in-situ direction was calculated at $\operatorname{Dec}=103^{\circ}$, Inc $=-53^{\circ}\left(\mathrm{k}=43, \alpha_{95}=7.4^{\circ}\right.$; Fig 8a). After correcting for minor tilt, the mean direction is $\operatorname{Dec}=99^{\circ}, \operatorname{Inc}=-59^{\circ}\left(\mathrm{k}=53, \alpha_{95}=7^{\circ}\right.$; Fig $\left.8 \mathrm{~b}\right)$. There is a slightly better grouping of directions in tilt-corrected coordinates and so we use the tilt-corrected direction in the discussion. The resultant tilt-corrected paleomagnetic pole falls at $9^{\circ} \mathrm{S}, 166^{\circ} \mathrm{E}\left(\mathrm{A} 95=9^{\circ}\right)$.

Our grand mean direction is nearly identical to the directions obtained by Brock et al. (1972; Table 1). The paper by Brock et al. (1972) does not report individual sample results (or $\alpha_{95}$ values). Based on the sketch map in Brock et al. (1972) and our own field observations, it appears that our sites 5 and 9 are identical to sites 13 and 4 sampled by Brock et al. (1972; Figure 1). Because of the limited data available in the original study, we calculated a tilt-corrected mean for our sites and a mean for the Brock et al. (1972) sites separately and then combined both into a grand mean using our results from sites 5 \& 9 and omitting the two identical sites in the Brock et al. (1972) paper. The grand mean (GM) calculated from both studies yields a Dec $=99^{\circ}$, Inc $=-59^{\circ}$ (17 sites; $\left.\mathrm{k}=33, \alpha_{95}=6^{\circ}\right)$ with a resultant paleomagnetic pole at $7^{\circ} \mathrm{S}, 166^{\circ} \mathrm{E}\left(\mathrm{A} 95=8^{\circ}\right)$.

Rock Magnetic Results

Rock magnetic studies carried out on a selected suite of samples from the andesites, felsites and basalts indicate that there are multiple remanence carriers in the samples. Isothermal remanence acquisition curves on basaltic samples (fig. 9) all show saturation by 0.2-0.3 T. This rapid saturation in relatively low applied fields is consistent with magnetite/low-Ti magnetite as a main carrier of remanence. Magnetite is also indicated in nearly all of the demagnetization intensity decay plots (figs. 5b, 6b and 7b) although an intensity decay at around $300-350^{\circ} \mathrm{C}$ (figs. $5 \mathrm{~b}, 7 \mathrm{~b}$ ) may indicate the presence of pyrrhotite in several samples. Curie temperature runs were conducted on a felsite sample (figs. 10a,b), a porphyritic basalt sample (figs. 10c,d) and a basalt sample (figs. 10e, f). All samples indicate some alteration during heating of the sample (compare susceptibility 
values in the heating versus cooling curves). The felsite sample shows a Curie temperature (heating) of $\sim 580^{\circ} \mathrm{C}$ typical of magnetite with an indication of a small amount of hematite (figs. 10a,b). The porphyritic basalt shows no clear Curie temperature during the heating phase, but upon cooling there is an indication of both hematite and magnetite (figs. 10c,d). The basalt sample shows a Curie temperature of $\sim 570^{\circ} \mathrm{C}$ in the heating curve with some hematite present (fig. 10e). The cooling curve also shows the presence of both hematite and magnetite (fig. 10f).

\section{Discussion}

Our study, combined with the earlier results published by Brock et al. (1971) refine the pole for the Kisii lavas. Field tests to constrain the age of the Kisii pole are indeterminate. Correction for local tilt results in a slightly better, but statistically insignificant, clustering ( $\mathrm{k}=28$ in-situ; k=33 tilt-corrected; Figs. 8a,b). We note that two sites in the upper part of the sequence are of the opposite polarity to the lower basaltic units and therefore the magnetization was acquired during at least one field reversal.

The main argument against a primary magnetization is that the Kisii pole falls on the apparent polar wander path for Gondwana 530-520 Ma (Meert and Van der Voo, 1996). We argue for a primary magnetization on the following basis: (a) metamorphism in the Kisii Series resulted from syn-genetic hydrothermal activity (forming the famous Kisii soapstone); (b) the Kisii Series was only slightly affected (by normal faulting) during the development of the East African rift; (c) the paleomagnetic directions in the Kisii Series are distinct from expected Miocene-recent directions in the East African rift (fig. 3); (d) the only structures in the Kisii Series associated with the East African Orogeny are $>50 \mathrm{~km}$ to the East of the study area (Aswa shear zone and Nandi Escarpment; Hetzel and Strecker, 1994; Sanders, 1965); (e) paleomagnetic directions from the later stages of the East African Orogeny in Kenya are distinct from the Kisii pole (Meert et al., 1996; fig. 3); (f) clasts in the underlying Kavirondian conglomerate are not remagnetized (see fig 1 for site) and; (g) The underlying Nyanzian lavas have a distinct paleomagnetic pole with field tests/geochronology constraining the age of magnetization to $\sim 2670$ Ma (fig. 3: Meert et al., 1994). According to Van der Voo's (1990) reliability criteria, the Kisii Series is assigned 
a Q-factor=5 (fails criteria \#4 and \#7). We treat the Kisii pole as a primary magnetization in the following discussion.

During the most recent Nordic paleomagnetic workshop (2014) all Archean-age poles were reviewed and ranked by committee. In the 2500-2700 Ma range, only 5 poles were considered 'key' for this interval. Of the 5 poles, 3 are from Fennoscandia, one from the Superior craton and one from the Zimbabwe craton. It is very difficult with the limited database to discuss crustal mobility or plate reconstructions. Three of the Fennoscandian poles are $\sim 2500 \mathrm{Ma}$ age, but each of the intrusions shows a very different paleomagnetic pole (Mertanen et al., 2006; Arestova et al., 2002; Pechersky et al., 2004). The Ptarmigan mean pole from the Superior craton (2505 $\pm 2 \mathrm{Ma}$; compilation in Evans and Halls, 2010) is considered reliable mainly due to its proximity to the slightly younger Matachewan dykes pole between 2446-2473 Ma (compilation in Evans and Halls, 2010). At this point, we feel it is premature to evaluate potential relationships between the Tanzanian craton and Fennoscandia or Superior.

It is possible to expand the database slightly and compare paleomagnetic poles from the Kaapvaal, Tanazanian and Zimbabwe nuclei in the 2500-2700 Ma interval. In the following analysis, we use paleomagnetic poles from the African nuclei $(\mathrm{Q} \geq 4$ that must include a reliable age; Table 2). There are two poles from the Tanzanian craton, two poles from the Zimbabwe craton and three poles from the Kaapvaal craton. The three poles from the Kaapvaal craton are of similar age, but the pole from the Mbabane pluton is different from the other two poles (Allanridge basalts and Rykoppies dykes; Table 2). Because of the lack of structural control on the pluton, we prefer comparisons to the dykes and basalts in our analysis.

If we assume Protopangea integrity during the Late Archean (Piper, 2010), then similar-age poles from the Tanzanian, Zimbabwe and Kaapvaal nuclei should be positioned in the same location because the Piper model insists on the tectonic coherence of Africa for the entirety of the Precambrian. Based on single poles at $2680 \mathrm{Ma}$ from the three nuclei, such an integrity is not supported (figs. 11 and 12; Table 2). We do note that the 
differences between the Zimbabwe and Kaapvaal cratons poles are only slightly larger than the maximum error on the pole positions (see Table 3).

For the $\sim 2550$ Ma time period, the pole from the Kisii lavas and the Great Dyke mean pole (Table 2 and 3) show a clear difference (angular distance between the two poles is at least $62^{\circ}$ ) indicating that the two regions were not in their present-day configuration as required by the Protopangea hypothesis. Furthermore, the APWP length for the pair of Zimbabwe poles (Belingwe-Great dyke mean) is $56^{\circ}$ versus $27^{\circ}$ for the Tanzanian pair (Nyanzian-Kisii). Thus, based on this limited dataset, it would appear that the Zimbabwe and Tanzanian cratons were most likely (a) moving independently as rigid blocks as opposed to true polar wander (TPW) since TPW requires similar-length apparent polar wander paths. TPW cannot be completely dismissed because of slight differences in the ages of the poles and errors associated with their positions. The dataset, while limited, does not support the Protopangea hypothesis (Piper, 2010) where the cratons must remain in a rigid configuration throughout the Archean and Paleoproterozoic. Figure 12 shows the three nuclei reconstructed according to the paleomagnetic data in Table 2 . In the reconstruction, we have positioned according to a particular polarity choice and attempted to minimize the longitudinal misfit between the Protopangean configuration (essentially the modern-day positions). Given the usual caveats (i.e. polarity choice, freedom of longitude, errors in pole positions), it is possible to closely approximate the present-day relationships between the Tanzanian craton and the Zimbabwe craton at $\sim 2.5$ Ga (Figure $12 \mathrm{~b}$ ), but not at $\sim 2.7$ Ga (figure $12 \mathrm{a}$ ).

\section{Conclusions}

We report an updated pole from the Kisii lavas in western Kenya at $7^{\circ} \mathrm{S}, 167^{\circ} \mathrm{E}$ $\left(A 95=7.4^{\circ}\right)$. Limited paleomagnetic data from the Tanzanian, Zimbabwe and Kaapvaal nuclei imply that their relative present-day geographic distribution was different from that during the Archean; although by choosing a specific polarity and longitudinal placement, it is possible to come close to the present-day geometry at $2.5 \mathrm{Ga}$. This conclusion negates the specific Protopangea model of Piper (2010) which requires poles to fall along a defined apparent polar wander path in their present-day African configuration. It is more difficult 
to ascertain the nature of motion implied by these data, although true polar wander during the 2700-2500 Ma range is difficult to reconcile with the APW lengths of the Tanzanian and Zimbabwe cratons. As future work provides additional quality poles for the Neoarchean, it may be easier to establish the nature of continental motion implied by these data.

Acknowledgements: Funding for the research in this project was provided by grants from the Geological Society of America (to JGM), Sigma Xi (to JGM), Scott Turner Fund (to JGM and RVDV), University of Michigan Rackham Dissertation Fellowship (to JGM), the Foundation "Stichting Dr. Schürmannfonds", grant no. 1993/02 (to RVDV) and the National Science Foundation grant EAR92-05815 (to RVDV). All conclusions in this paper reflect those of the authors and not the funding agencies. We also thank Michiel de Kock and David Evans for very thorough and thoughtful reviews of the manuscript.

\section{References}

Arestova, N.A., Khramov, A.N., Gooskova, E.G., Iosifidi, A.G., 2002. New paleomagnetic evidence from the Early Proterozoic (2.5-2.46 Ga) Mount Generalskaya and Imandra layered intrusions, Kola Peninsula, Fizika Zemli, 38, 65-76.

Bercovici, D. and Ricard, Y., 2014. Plate tectonics, damage and inheritance, Nature, 508, 513-516.

Briden, J.C., Piper, J.D.A., Henthorn, D.I. and Rex, D.C., 1971. New paleomagnetic results from Africa and related potassium-argon age determinations. 15 ${ }^{\text {th }}$ Annual Report Research Institute of African Geology, University of Leeds, 46-50.

Brock, A., Raja, P.K.S., Vise, J.B., 1972. The palaeomagnetism of the Kisii Series, western Kenya. Geophysical Journal of the Royal Astronomical Society, 28, 129-137.

Brock, A. and Piper, J.D.A., 1972. Interpretation of Late Precambrian paleomagnetic results from Africa, Geophysical Journal of the Royal Astronomical Society, 28, 139-146.

Buchan, K.L., Mertanen, S., Park, R.G., Pesonen, L.J., Elming, S.A., Abrahamsen, N., Bylund, G., 2000. Comparing the drift of Laurentia and Baltica in the Proterozoic: The importance of key paleomagnetic poles, Tectonophysics, 319, 167-198.

Cahen, L. and Snelling, N.J. 1974. Potassium-argon ages and additions to the stratigraphy of the Malagarasian (Bukoban System of Tanzania) of SE Burundi, Journal of the Geological Society of London, 130, 461-470.

Cahen, L., Snelling, N.J., Delhal, J., Vail, J.R., 1984. The Geochronology and Evolution of Africa, Clarendon Press, Oxford (UK), $512 \mathrm{pp}$.

Cawood, P., Kroner, A., Pisarevsky, S.A., 2006. Precambrian plate tectonics:criteria and evidence, GSA Today, 16, 4-11.

Charlton, S., 1973. Limitations of the Argon-39 method on Precambrian dolerites. 16 $6^{\text {th }}$ Annual Report Research Institute of African Geology, University of Leeds, 45-47.

Chauvel, C., Dupre, B., Todt, W., Arndt, N.T., 1983. Pd and ND isotopic correlation in Belingwe komatiites and basalts, IN: Bickle, M.J. and Nisbet, E.G. (eds), The Geology of the Belingwe 
Greenstone Belt, Zimbabwe: A study of the evolution of Archean continental crust, Geological Survey of Zimbabwe Special Publication \#2, Rotterdam, Balkema, 167-174.

Condie, K.C., Pease, V., 2008. When did plate tectonics begin on planet Earth? Geological Society of America Special Paper 440, v-viii.

Davies, G., 1992. On the emergence of plate tectonics, Geology, 20, 963-966.

Deblond, A., Punzalan, L.E., Boven, A., Tack, L., 2001. The Malagarazi Supergroup of southeast Burundi and its correlative Bukoba Supergroup of northeast Tanzania: Neo and Mesoproterozoic chronostratigraphic constraints from Ar-Ar ages on mafic intrusive rocks, Journal of African Earth Sciences, 32, 435-449.

De Kock, M., Evans, D.A.D., Beukes, N.J., 2009. Validating the existence of Vaalbara in the Neoarchean, Precambrian Research, 174, 145-154.

Evans, D.A.D., Pisarevsky, S.A., 2008. Plate tectonics on early Earth?, Geological Society of America Special Paper 440, 249-263.

Evans, D.A.D., Halls, H.C., 2010. Restoring Proterozoic deformation within the Superior craton, Precambrian Research, 183, 474-489.

Hamilton WB. 2011. Plate tectonics began in Neoproterozoic time, and plumes from deep mantle have never operated. Lithos 123, 1-20.

Hetzel, R. and Strecker, M.R., 1994. Late Mozambique Belt structures in western Kenya and their influence on the evolution of the Cenozoic Kenya Rift, Journal of Structural Geology, 16, 189201.

Huddleston, A., 1951. Geology of the Kisii District, Report \#18, Geological Survey of Kenya, Government Printer, Nairobi, 65 pp.

Kabete, J.M., Groves, D.I., McNaughton, N.J., Mruma, A.H., 2012a. A new tectonic and temporal framework for the Tanzanian Shield: Implications for gold metallogeny and undiscovered endowment, Ore Geology Reviews, 48, 88-124.

Kabete, J.M., McNaughton, N.J., Groves, D.I., Mruma, A.H., 2012b. Reconnaisance SHRIMP U-Pb zircon geochronology of the Tanzanian craton: Evidence for NeoArchean granitoidgreenstone belts in the central Tanzanian region and the southern East Africa Orogen, Precambrian Research, 216-219, 232-266.

Korenaga, Y., 2013. Initiation and evolution of plate tectonics on Earth: Theories and observations, Annual Reviews of Earth and Planetary Sciences, 41, 117-151.

Layer, P.W., Kroner, A., McWilliams, M. and York, D., 1989. Elements of the Archean thermal history and apparent polar wander path of the eastern Kaapvaal craton, Swaziland, from singlegrain dating and paleomagnetism, Earth and Planetary Science Letters, 93, 23-34.

Lubnina, N., Ernst, R., Klausen, M., Soderlund, U., 2010. Paleomagnetic study of NeoarcheanPaleoproterozoic dykes in the Kaapvaal craton, Precambrian Research, 183, 523-552. 
Meert, J.G., 1993. Precambrian Tectonics: Some constraints from paleomagnetic studies in North America and Africa (dissertation), University of Michigan Publications, Ann Arbor, MI, pp. 129-140.

Meert, J.G., Van der Voo, R. and Patel, J.P., 1994. Paleomagnetism of the Late Archean Nyanzian System, western Kenya, Precambrian Research, 69, 113-131.

Meert, J.G., Van der Voo, R., Ayub, S., 1995. Paleomagnetic investigation of the Neoproterozoic Gagwe lavas and Mbozi Complex, Tanzania and the assembly of Gondwana, Precambrian Research, 74, 225-244.

Meert, J.G. and Van der Voo, R., 1996. Paleomagnetic and ${ }^{40} \mathrm{Ar} /{ }^{39} \mathrm{Ar}$ study of the Sinyai dolerite, Kenya: Implications for Gondwana assembly, Journal of Geology, 104, 131-142.

Meert, J.G. and Torsvik, T.H., 2003. The making and unmaking of a supercontinent:Rodinia Revisited, Tectonophysics, 375, 261-288.

Meert, J.G. and Torsvik, T.H., 2004. Reply to JDA Piper: The making and unmaking of a Supercontinent, Tectonophysics, 383, 99-103.

Meert, J.G., 2003. A synopsis of events related to the assembly of eastern Gondwana, Tectonophysics, 362, 1-40.

Meert, J.G., 2014. Strange Attractors, Spiritual Interlopers and Lonely Wanderers: The Search for Pre-Pangæan Supercontinents. Geoscience Frontiers, 5, 155-166.

Mertanen, S., Vuollo, J.I., Huhma, H., Arestova,. N.A., Kovalenko, A., 2006. Early PaleoproterozoicArchean dykes and gneisses in Russian Karelia of the Fennoscandian shield-new paleomagnetic isotopic age and geochemical investigations, Precambrian Research, 144, 239-260.

Moore, W.B., Webb, A.A.G., 2013, Heat-pipe Earth. Nature, 501, p. 501-505.

Moores, E.M., 1993. Neoproterozoic oceanic crustal thinning, emergence of continents and the origin of Phanerozoic ecosystems: A model, Geology, 21, 5-8.

Ngecu, W.M., Gaciri, S.J., 1995. Lithostratigraphy, provenance and facies distribution of Archean cratonic succession in western Kenya, Journal of African Earth Sciences, 21, 359-372.

Patel, J.P. and Raja, P.K.S., 1979. A palaeomagnetic study of lower Proterozoic granites from western Kenya, Geophysical Journal of the Royal Astronomical Society, 58, 279-286.

Patel, J.P., 1989. Paleomagnetic results from late Archean and Early Proterozoic granites from southwestern Kenya, Journal of African Earth Sciences, 9, 97-100.

Pechersky, D.M., Zakharov, V.S., Lyubushin, A.A., 2004. Continuous record of geomagnetic field variations during cooling of the Monchegorsk, Kivakka and Bushveld Early Proterozoic layered intrusions, Russian Journal of Earth Science, 6, 391-456.

Pinna, P., Cocherie, A., Thieblemont, D., Jezequel, P., 2000. The Kisii Group of western Kenya: an end Archean $(2.53 \mathrm{Ga})$ late orogenic volcano sedimentary sequence, Journal of African Earth Sciences, 30, 79-97. 
Piper, J.D.A., 1972. A paleomagnetic study of the Bukoban System, Tanzania. Geophysical Journal of the Royal Astronomical Society, 28, 111-127.

Piper, J.D.A., 2010. Protopangea:Paleomagnetic definition of Earth's (mid-ArcheanPaleoproterozoic) oldest supercontinent, Journal of Geodynamics, 50, 154-165.

Piper, J.D.A., 2013. A planetary perspective on Earth Evolution: Lid tectonics before plate tectonics, Tectonophysics, 589, 44-56.

Sanders, L.D., 1965. Geology of the contact between the Nyanza shield and the Mozambique Belt in western Kenya, Geological Survey of Kenya Bulletin \#7, 45 pp.

Saggerson, E.P., 1952. Geology of the Kisumu District, Report \#21, Geological Survey of Kenya, Government Printer, Nairobi, 84 pp.

Schoeman, J.J., 1949. Geology of the Sotik District, Report \#16, Geological Survey of Kenya, Government Printer, Nairobi, 39 pp.

Shackleton, R.M., 1948. The geology of the Migori gold belt, Report \#10, Geological Survey of Kenya, Government Printer, Nairobi, 60 pp.

Shirey, S.B. and Richardson, S.H., 2011. Start of the Wilson Cycle at 3.0 Ga shown by diamonds from subcontinental mantle, Science, 333, 434-436.

Smirnov, A., Evans, D.A.D., Ernst, R.E., Soderlund, U., Li, Z-X, 2013. Trading partners: tectonic ancestry of southern Africa and western Australia, in Archean supercratons Vaalbara and Zimgarn, Precambrian Research, 224, 11-22.

Stern, R.J. 2005. Evidence from Ophiolites, Blueschists, and Ultra-High Pressure Metamorphic Terranes that the Modern Episode of Subduction Tectonics Began in Neoproterozoic Time. Geology 33, 557-560.

Stern, R.J. 2008. Modern-Style Plate Tectonics Began in Neoproterozoic Time: An Alternative Interpretation of Earth's Tectonic History. Condie, K., and Pease, V., eds, When did Plate Tectonics Begin?, Geological Society of America Special Paper 440, 265-280.

Strik, G., de Wit, M.J., Langereis, C.G., 2007. Paleomagnetism of the Neoarchean Pongola and Ventersdorp Supergroups and an appraisal of the 3.0-1.9 Ga apparent polar wander path of the Kaapvaal craton, southern Africa, Precambrian Research, 153, 96-115.

Wingate, M.T.D., 2000. Ion microprobe U-Pb zircon and baddeleyite ages for the Great Dyke and its satellite dykes, Zimbabwe, South African Journal of Geology, 103, 74-80.

Yoshihara, A. and Hamano, Y., 2004. Paleomagnetic constraints on the Archean geomagnetic field intensity obtained from komatiites of the Barbeton and Belingwe greenstone belts, South Africa and Zimbabwe, Precambrian Research, 131, 111-142. 
Figure Legends

Figure 1. (a) Geological sketch map of the sampling region (after Huddleston, 1951 and Schoeman, 1949). Sampling sites from this study are indicated by white squares and letter S\#. Sites sampled by Brock et al. (1972) are given by site number (see table 1). , Geochronology sampling site given by red star (Pinna et al., 2000), KC7 is the site location for the Kavirondian conglomerate sampled by Meert et al (1994). (b) Inset map showing the study area in a more regional context including the Tanzanian, Zimbabwe and Kaapvaal nuclei.

Figure 2. Generalized stratigraphy of the Kisii region. Ages are summarized in Kabete et al. (2012) and/or Meert et al. (1994).

Figure 3: Plot of the Kisii lavas paleomagnetic pole along with previously published poles from Kenya/Tanzania and the Late Ediacaran-Cambrian APWP for Gondwana.

Figure 4: (a) Orthogonal vector diagram for sample VKC-22; (b) Intensity decay plot and; (c) stereoplot for sample VKC-22. Closed/Open circles on stereoplots represent positive/negative inclinations.

Figure 5: (a) Orthogonal vector diagram for sample VKC-45; (b) Intensity decay plot and; (c) stereoplot for sample VKC-45. Symbols same as in figure 3.

Figure 6: (a) Orthogonal vector diagram for sample VKC-39; (b) Intensity decay plot and; (c) stereoplot for sample VKC-39. Symbols same as in figure 3

Figure 7: (a) Orthogonal vector diagram for sample JKA-3; (b) Intensity decay plot and; (c) stereoplot for sample JKA-3. Symbols same as in figure 3.

Figure 8: (a) Stereoplot showing mean site directions and $\alpha_{95}$ errors in-situ; (b) Stereoplot showing mean site directions and $\alpha_{95}$ errors in tilt-corrected coordinates; (c) plot of VGP's calculated from individual sites (red=study by Brock et al., 1972; Navy=this study). See Table 1 for individual results.

Figure 9: Isothermal remanence acquisition curves for a variety of samples used in this study. All show saturation by 0.3 Tesla.

Figure 10: Curie temperature runs for (a) heating curve for felsite; (b) cooling curve for felsite ; (c) heating curve for porphyritic basalt; (d) cooling curve for porphyritic basalt; (e) heating curve for basalt; (f) cooling curve for basalt. 
Figure 11: Poles from the Tanzanian, Zimbabwe and Kaapvaal cratons for the 2700-2500 Ma intervals.

Figure 12: (a) Reconstruction of the Kaapvaal, Zimbabwe and Tanzanian cratons at $\sim 2700$ Ma based on the paleomagnetic poles listed in Table 2. K27a=Rykoppies pole; K27b=Allanridge basalts; Z27=Belingwe komatiites; T27=Nyanzian lavas. The outline of modern-day Africa is reconstructed to the Nyanzian pole for ease of evaluating the Paleopangean misfit; (b) Reconstruction of the Zimbabwe and Tanzanian cratons at 2550 Ma based on paleomagnetic poles in Table 2. Z25=Great dyke mean; T25=Kisii lavas. The outline of modern-day Africa and presentday positions of the Kaapvaal and Zimbabwe cratons are reconstructed to the Kisii pole for ease of evaluating the Paleopangean misfit. 
Table 1. Paleomagnetic Results

\begin{tabular}{|c|c|c|c|c|c|c|c|c|c|c|c|c|}
\hline Site & Lat/Long $^{1}$ & $n / N$ & $\mathrm{Dg}$ & Ig & Ds & Is & $\mathbf{k}$ & $\alpha_{95}$ & Plat & Plong & $d p$ & $\mathrm{dm}$ \\
\hline 1 & $0^{\circ} 35^{\prime} \mathrm{S}, 34^{\circ} 49^{\prime} \mathrm{E}$ & $8 / 9$ & $94^{\circ}$ & $-51^{\circ}$ & $88^{\circ}$ & $-58^{\circ}$ & 23 & $10^{\circ}$ & $2^{\circ} \mathrm{N}$ & $163^{\circ} \mathrm{E}$ & $11^{\circ}$ & $15^{\circ}$ \\
\hline 2* & $0^{\circ} 34^{\prime} \mathrm{S}, 34^{\circ} 47^{\prime} \mathrm{E}$ & $9 / 9$ & $122^{\circ}$ & $-37^{\circ}$ & $112^{\circ}$ & $-46^{\circ}$ & 47 & $5^{\circ}$ & $19^{\circ} \mathrm{S}$ & $154^{\circ} \mathrm{E}$ & $4^{\circ}$ & $6^{\circ}$ \\
\hline 4 & $0^{\circ} 36^{\prime} \mathrm{S}, 34^{\circ} 46^{\prime} \mathrm{E}$ & $6 / 6$ & $102^{\circ}$ & $-53^{\circ}$ & $92^{\circ}$ & $-61^{\circ}$ & 9 & $19^{\circ}$ & $1^{\circ} \mathrm{S}$ & $168^{\circ} \mathrm{E}$ & $22^{\circ}$ & $29^{\circ}$ \\
\hline 7 & $0^{\circ} 49.5 \mathrm{~S}, 34^{\circ} 44^{\prime} \mathrm{E}$ & $6 / 9$ & $101^{\circ}$ & $-53^{\circ}$ & $103^{\circ}$ & $-57^{\circ}$ & 12 & $17^{\circ}$ & $10^{\circ} \mathrm{S}$ & $163^{\circ} \mathrm{E}$ & $18^{\circ}$ & $24^{\circ}$ \\
\hline 9 & $0^{\circ} 48.5 \mathrm{~S}, 34^{\circ} 43^{\prime} \mathrm{E}$ & $7 / 7$ & $104^{\circ}$ & $-80^{\circ}$ & $117^{\circ}$ & $-85^{\circ}$ & 228 & $4^{\circ}$ & $4^{\circ} \mathrm{S}$ & $206^{\circ} \mathrm{E}$ & $7^{\circ}$ & $7^{\circ}$ \\
\hline $10^{*}$ & $0^{\circ} 40^{\prime} \mathrm{S}, 34^{\circ} 47.3^{\prime} \mathrm{E}$ & $6 / 11$ & $100^{\circ}$ & $-36^{\circ}$ & $97^{\circ}$ & $-44^{\circ}$ & 14 & $15^{\circ}$ & $6^{\circ} \mathrm{S}$ & $151^{\circ} \mathrm{E}$ & $12^{\circ}$ & $19^{\circ}$ \\
\hline 11 & $0^{\circ} 39.8 \mathrm{~S}, 34^{\circ} 44.5^{\prime} \mathrm{E}$ & $9 / 9$ & $96^{\circ}$ & $-30^{\circ}$ & $94^{\circ}$ & $-37^{\circ}$ & 32 & $8^{\circ}$ & $4^{\circ} \mathrm{S}$ & $145^{\circ} \mathrm{E}$ & $6^{\circ}$ & $10^{\circ}$ \\
\hline 13 & $0^{\circ} 40^{\prime} \mathrm{S}, 34^{\circ} 44.8^{\prime} \mathrm{E}$ & $5 / 9$ & $106^{\circ}$ & $-54^{\circ}$ & $101^{\circ}$ & $-62^{\circ}$ & 31 & $11^{\circ}$ & $8^{\circ} \mathrm{S}$ & $169^{\circ} \mathrm{E}$ & $14^{\circ}$ & $18^{\circ}$ \\
\hline $15^{*}$ & $0^{\circ} 40^{\prime} \mathrm{S}, 34^{\circ} 46^{\prime} \mathrm{E}$ & $7 / 11$ & $93^{\circ}$ & $-71^{\circ}$ & $76^{\circ}$ & $-78^{\circ}$ & 63 & $7^{\circ}$ & $6^{\circ} \mathrm{S}$ & $192^{\circ} \mathrm{E}$ & $12^{\circ}$ & $13^{\circ}$ \\
\hline BMean & & 9 Sites & $103^{\circ}$ & $-52^{\circ}$ & $99^{\circ}$ & $-59^{\circ}$ & 25 & $10^{\circ}$ & $7^{\circ} \mathrm{S}$ & $166^{\circ} \mathrm{E}$ & $A 95=$ & \\
\hline 4 & $0^{\circ} 42 .^{\prime} \mathrm{S}, 34^{\circ} 46^{\prime} \mathrm{E}$ & $4 / 6$ & $106^{\circ}$ & $-48^{\circ}$ & $102^{\circ}$ & $-53^{\circ}$ & 197 & $6^{\circ}$ & $9^{\circ} \mathrm{S}$ & $159^{\circ} \mathrm{E}$ & $6^{\circ}$ & $8^{\circ}$ \\
\hline 5 & $0^{\circ} 40^{\prime} \mathrm{S}, 34^{\circ} 44.8^{\prime} \mathrm{E}$ & $7 / 9$ & $111^{\circ}$ & $-54^{\circ}$ & $120^{\circ}$ & $-58^{\circ}$ & 76 & $9^{\circ}$ & $23^{\circ} \mathrm{S}$ & $168^{\circ} \mathrm{E}$ & $10^{\circ}$ & $13^{\circ}$ \\
\hline 6 & $0^{\circ} 39 .^{\prime} \mathrm{S}, 34^{\circ} 44.9^{\prime} \mathrm{E}$ & $8 / 8$ & $87^{\circ}$ & $-62^{\circ}$ & $97^{\circ}$ & $-69^{\circ}$ & 288 & $3^{\circ}$ & $4^{\circ} \mathrm{S}$ & $177^{\circ} \mathrm{E}$ & $4^{\circ}$ & $5^{\circ}$ \\
\hline 7 & $0^{\circ} 39.8^{\prime} \mathrm{S}, 34^{\circ} 44.7^{\prime} \mathrm{E}$ & $16 / 16$ & $105^{\circ}$ & $-42^{\circ}$ & $103^{\circ}$ & $-53^{\circ}$ & 66 & $5^{\circ}$ & $11^{\circ} \mathrm{S}$ & $158^{\circ} \mathrm{E}$ & $5^{\circ}$ & $7^{\circ}$ \\
\hline 8 & $0^{\circ} 39.7 \mathrm{~S}, 34^{\circ} 44.8^{\prime} \mathrm{E}$ & $11 / 15$ & $103^{\circ}$ & $-36^{\circ}$ & $105^{\circ}$ & $-45^{\circ}$ & 155 & $5^{\circ}$ & $13^{\circ} \mathrm{S}$ & $153^{\circ} \mathrm{E}$ & $4^{\circ}$ & $6^{\circ}$ \\
\hline 9 & $0^{\circ} 36^{\prime} \mathrm{S}, 34^{\circ} 46^{\prime} \mathrm{E}$ & $8 / 10$ & $106^{\circ}$ & $-53^{\circ}$ & $97^{\circ}$ & $-61^{\circ}$ & 120 & $6^{\circ}$ & $5^{\circ} \mathrm{S}$ & $167^{\circ} \mathrm{E}$ & $7^{\circ}$ & $9^{\circ}$ \\
\hline 12 & $0^{\circ} 57^{\prime} \mathrm{S}, 34^{\circ} 51^{\prime} \mathrm{E}$ & $4 / 7$ & $99^{\circ}$ & $-60^{\circ}$ & $106^{\circ}$ & $-53^{\circ}$ & 111 & $9^{\circ}$ & $13^{\circ} \mathrm{S}$ & $160^{\circ} \mathrm{E}$ & $9^{\circ}$ & $13^{\circ}$ \\
\hline 13 & $0^{\circ} 56.5^{\prime} \mathrm{S}, 34^{\circ} 43.5^{\prime} \mathrm{E}$ & $4 / 7$ & $72^{\circ}$ & $-75^{\circ}$ & $67^{\circ}$ & $-80^{\circ}$ & 516 & $4^{\circ}$ & $9^{\circ} \mathrm{N}$ & $195^{\circ} \mathrm{E}$ & $7^{\circ}$ & $8^{\circ}$ \\
\hline 14 & $0^{\circ} 39^{\prime} \mathrm{S}, 34^{\circ} 52^{\prime} \mathrm{E}$ & $5 / 6$ & $286^{\circ}$ & $48^{\circ}$ & $277^{\circ}$ & $52^{\circ}$ & 201 & $7^{\circ}$ & $6^{\circ} \mathrm{S}$ & $158^{\circ} \mathrm{E}$ & $7^{\circ}$ & $10^{\circ}$ \\
\hline 15 & $0^{\circ} 34^{\prime} \mathrm{S}, 35^{\circ} 01^{\prime} \mathrm{E}$ & $4 / 6$ & $291^{\circ}$ & $51^{\circ}$ & $282^{\circ}$ & $54^{\circ}$ & 87 & $8^{\circ}$ & $10^{\circ} \mathrm{S}$ & $160^{\circ} \mathrm{E}$ & $8^{\circ}$ & $11^{\circ}$ \\
\hline MMean & & 10 Sites & $103^{\circ}$ & $-53^{\circ}$ & $99^{\circ}$ & $-59^{\circ}$ & 53 & $7^{\circ}$ & $9^{\circ} \mathrm{S}$ & $166^{\circ} E$ & $A 95=9^{\circ}$ & \\
\hline Grand Mean** & & 17 Sites & $103^{\circ}$ & $-53^{\circ}$ & $99^{\circ}$ & $-59^{\circ}$ & 33 & $6^{\circ}$ & $7^{\circ} \mathrm{S}$ & $166^{\circ} \mathrm{E}$ & $A 95=8^{\circ}$ & \\
\hline
\end{tabular}

$\mathrm{N}=$ number of samples collected; $\mathrm{n}=$ number of samples used in study; $\mathrm{Dg}=$ declination in geographic coordinates; Ig=inclination in geographic coordinates; Ds=declination in stratigraphic coordinates; Is=Inclination in stratigraphic coordinates; k=Fisher's (1953) kappa precision parameter (tilt-corrected); $\alpha_{95}=$ cone of $95 \%$ confidence about the mean direction (title-corrected); Plat=Pole latitude; Plong=Pole longitude; $\mathrm{dp}, \mathrm{dm}=$ cone of $95 \%$ confidence about the virtual geomagnetic pole in the co-latitude direction (dp) and orthogonal to the co-latitude direction ( $\mathrm{dm}$ ); A95 $=95 \%$ confidence circle about the mean paleomagnetic pole (tilt-correctred). BMean=Mean from the study of Brock et al. (1972); MMean= mean from sites sampled for this study.

${ }^{1}$ Lat, Long estimated from map. No GPS coordinates*Tilt-corrected pole recalculated from the original study.

**Grand mean uses our sites 5 and 9 and omits Brock's sites 4 and 13 

Table 2. Selected Poles From the Tanzanian, Zimbabwe and Kaapvaal Cratons

\begin{tabular}{|l|l|l|l|l|l|l|l|}
\hline Pole Name & Craton & Age & Plat & Plong & A95 & Q-rating & Reference \\
\hline & & & & & & & \\
\hline Nyanzian Lavas & Tanzanian & $2680 \pm 10 \mathrm{Ma}$ & $-14^{\circ}$ & $330^{\circ}$ & $6^{\circ}$ & 6 & Meert et al., 1994 \\
\hline Kisii Lavas & Tanzanian & $2531 \pm 2 \mathrm{Ma}$ & $7^{\circ}$ & $347^{\circ}$ & $7^{\circ}$ & 5 & This study; Brock et al., 1972; Pinna et al., 2000 \\
\hline & & & & & & & \\
\hline Belingwe & Zimbabwe & $2692 \pm 9 \mathrm{Ma}$ & $-45^{\circ}$ & $303^{\circ}$ & $19^{\circ}$ & 4 & Yoshihara and Hamano, 2004; Chauvel et al., 1983 \\
\hline Great Dyke Mean & Zimbabwe & $2574 \pm 2 \mathrm{Ma}$ & $22^{\circ}$ & $060^{\circ}$ & $3^{\circ}$ & 5 & Smirnov et al., 2013; Wingate, 2000 \\
\hline & & & & & & & \\
\hline Mbabane Pluton & Kaapvaal & $2685 \pm 5 \mathrm{Ma}$ & $-20^{\circ}$ & $286^{\circ}$ & $5^{\circ}$ & 4 & Layer et al., 1989 \\
\hline Rykoppies dykes & Kaapvaal & $\sim 2650 \mathrm{Ma}$ & $-62^{\circ}$ & $336^{\circ}$ & $7^{\circ}$ & 6 & Lubnina et al., 2010 \\
\hline Allanridge basalts & Kaapvaal & $2642 \pm 3 \mathrm{Ma}$ & $-69^{\circ}$ & $346^{\circ}$ & $4^{\circ}$ & 5 & De Kock et al., 2009; Strik et al., 2007 \\
\hline
\end{tabular}

Plat=pole latitude; Plong=pole longitude; $A 95=$ cone of $95 \%$ confidence about the mean pole; Q-rating according

to Van der Voo (1990); Euler poles for reconstructions in Fig 12 are as follows (a) 2700 Ma: Tanzanian craton Lat: $0^{\circ}$; Long: 60 $0^{\circ}$; Rotation $104^{\circ}$ clockwise; Kaapvaal-Ryk Lat: $6^{\circ}$; Long: $41^{\circ}$; Rotation $155^{\circ}$ clockwise; Kaapvaal-All; Lat: $7^{\circ}$; Long: $36^{\circ}$; Rotation $164^{\circ}$ clockwise; Zimbabwe Lat: $3^{\circ}$; Long: $220^{\circ}$; Rotation $135^{\circ}$ counter-clockwise (b) $\sim 2500 \mathrm{Ma}$ Tanzanian craton Lat: $0^{\circ}$; Long: $257^{\circ}$; Rotation $83^{\circ}$ counter-clockwise; Zimbabwe craton Lat: $18^{\circ}$; Long: $343^{\circ}$; Rotation $72^{\circ}$ counter-clockwise. 
Table 3. Great Circle Analysis

\begin{tabular}{|c|c|c|c|}
\hline Pole A & Pole B & Age & $\begin{array}{c}\text { Great Circle Distance } \\
\text { between poles }\end{array}$ \\
\hline Nyanzian Lavas (T) & Belingwe (Z) & $2680 \mathrm{Ma}$ & $38^{\circ}\left(\min 14^{\circ}\right)$ \\
\hline Nyanzian Lavas (T) & Rykoppies (K) & $2680 \mathrm{Ma}$ & $48^{\circ}\left(\min 34^{\circ}\right)$ \\
\hline Nyanzian Lavas (T) & Allanridge (K) & $2680 \mathrm{Ma}$ & $56^{\circ}\left(\min 46^{\circ}\right)$ \\
\hline Nyanzian Lavas (T) & Mbabane (K) & $2680 \mathrm{Ma}$ & $42^{\circ}\left(\min 31^{\circ}\right)$ \\
\hline Belingwe (Z) & Rykoppies (K) & $2680 \mathrm{Ma}$ & $25^{\circ}\left(\min 0^{\circ}\right)$ \\
\hline Belingwe (Z) & Allanridge (K) & $2680 \mathrm{Ma}$ & $32^{\circ}\left(\min 13^{\circ}\right)$ \\
\hline Belingwe (Z) & Mbabane (K) & $2680 \mathrm{Ma}$ & $29^{\circ}\left(\min 5^{\circ}\right)$ \\
\hline Kisii (T) & Great Dyke (Z) & $2550 \mathrm{Ma}$ & $73^{\circ}\left(\min 62^{\circ}\right)$ \\
\hline Belingwe (Z) & Great Dyke (Z) & $\Delta=118 \mathrm{Ma}$ & $56^{\circ}$ \\
\hline Nyanzian (T) & Kisii Lavas (T) & $\Delta=149 \mathrm{Ma}$ & $27^{\circ}$ \\
\hline
\end{tabular}

Note: The minimum distance is based on $\alpha_{95}$ error envelopes between the two poles. 

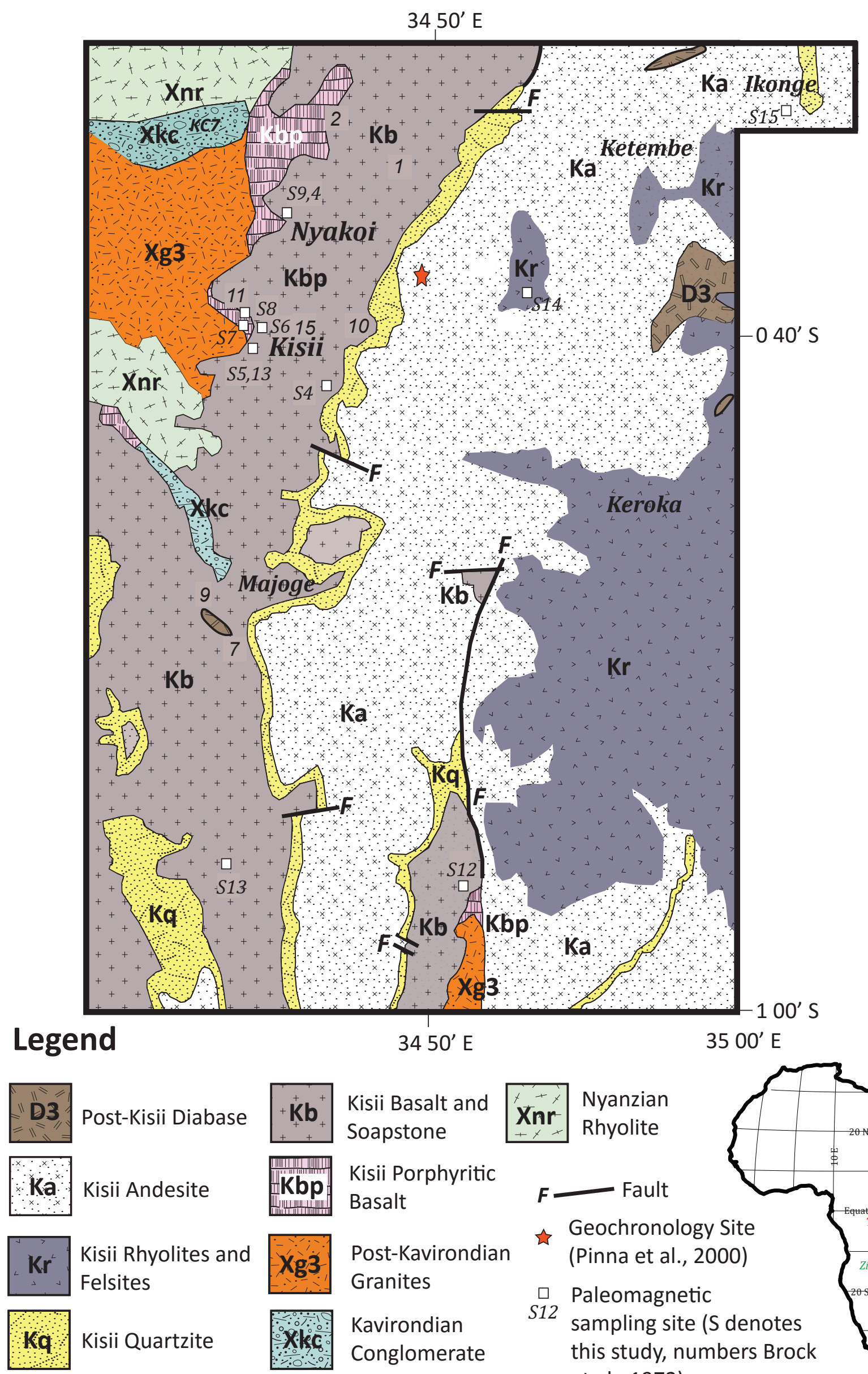

Kisii Basalt and Soapstone Kisii Porphyritic Basalt

Post-Kavirondian Granites

Kavirondian Conglomerate

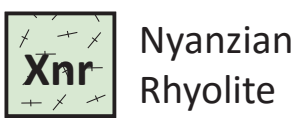

$\boldsymbol{F} \longrightarrow$ Fault

Geochronology Site (Pinna et al., 2000)

$\square$ Paleomagnetic

S12 sampling site (S denotes this study, numbers Brock

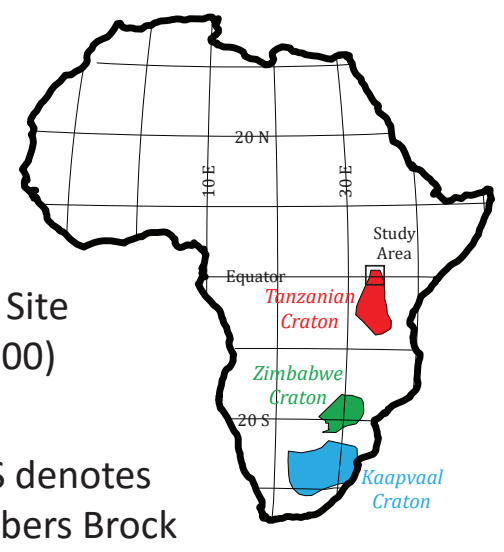
et al., 1972)

$\boldsymbol{K C} \mathbf{C}=$ Site of Kavirondian conglomerate test (Meert et al., 1994) 


\section{Generalized Stratigraphic Relationships in the Kisii Region}

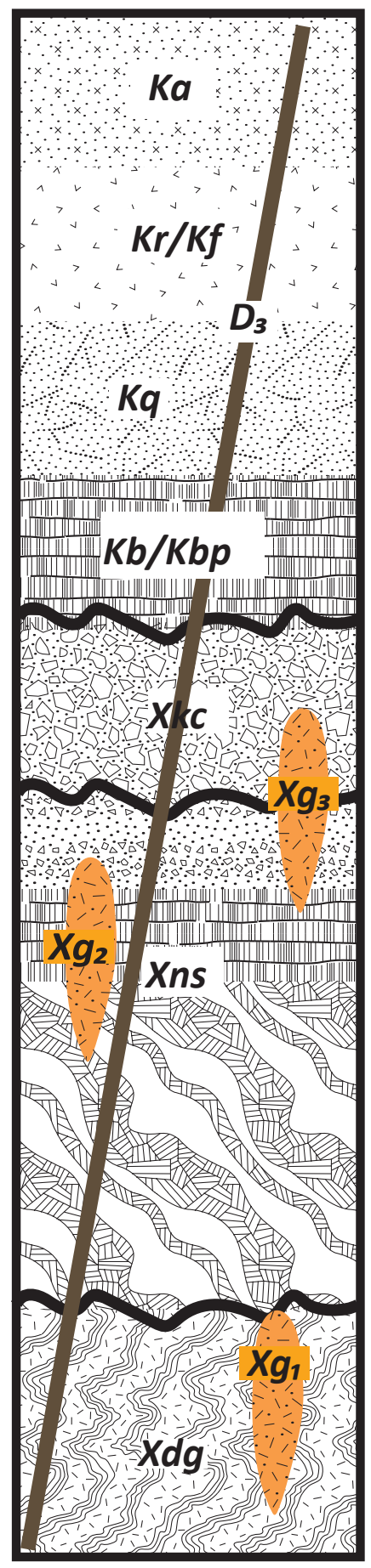

D $_{\mathbf{3}}$ : Post-Kisii dykes $<2530 \mathrm{Ma}$

Ka: Kisii andesite

Kr/Kf: Kisii felsite $2531 \mathrm{Ma}$

Kq: Kisii quartzite

Kb/Kbp: Kisii basalts and porphyritic basalts.

$\mathrm{Xg}_{3}$ : Post-Kavirondian granites.

$<2650 \mathrm{Ma}$ and $>2531 \mathrm{Ma}$

Xkc: Kavirondian conglomerate

and sedimentary rocks. $<2650 \mathrm{Ma}$

$\mathrm{Xg}_{2}$ : Post-Nyanzian granites

2650-2680 Ma. Deformation

at $2650 \mathrm{Ma}$

Xns: Nyanzian System volcanics (rhyolites, basalts, andesites) and banded iron formation. 2800-2700 Ma

$\mathbf{X g}_{1}$ : Older granites $<3100 \mathrm{Ma}$ and $>2800 \mathrm{Ma}$

Xdg: Dodoman gneisses and local basement schists. >3600 Ma to $3100 \mathrm{Ma}$

$\sim$ Unconformity 


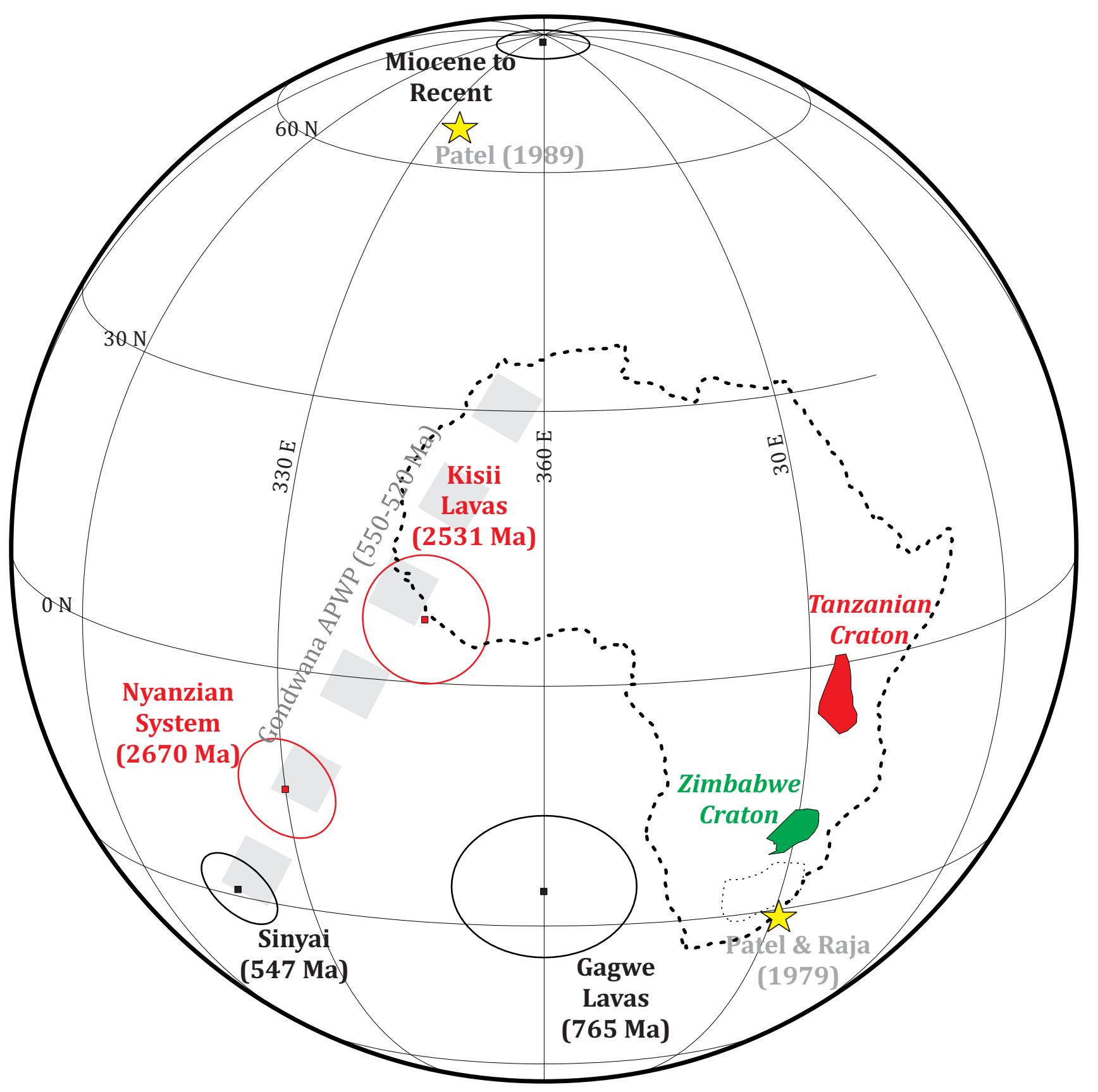




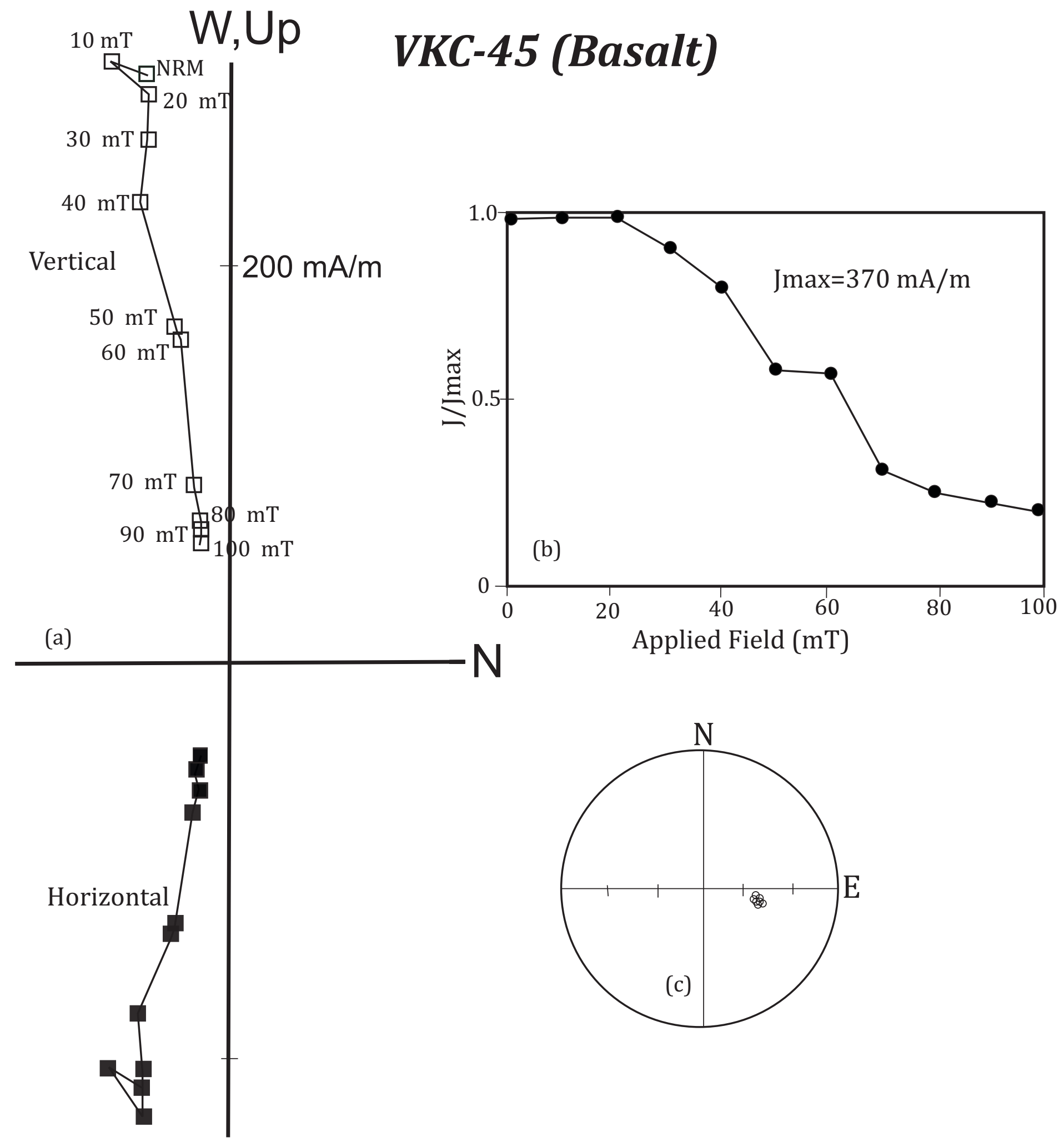




\section{VKC-22 (Basalt)}

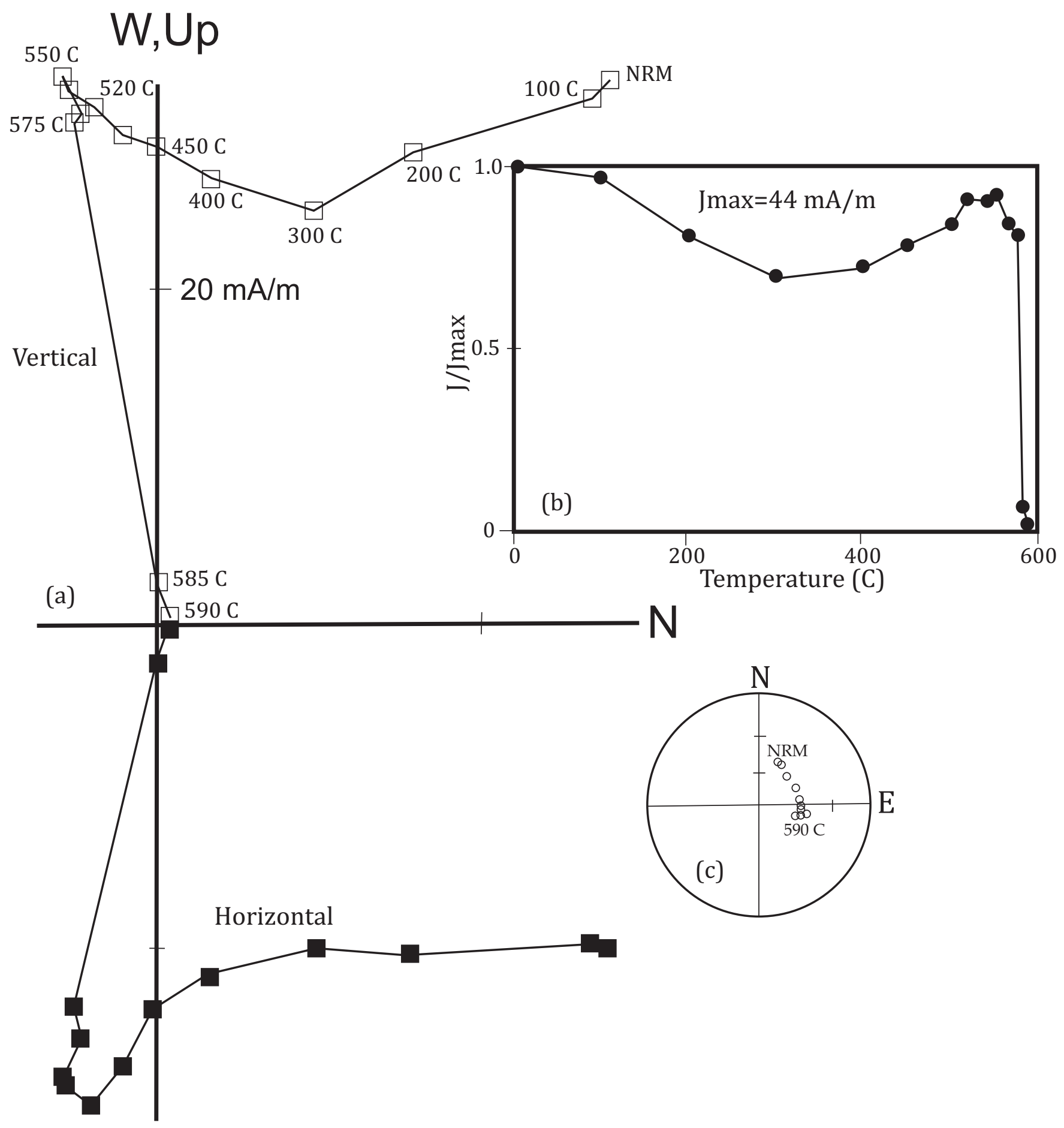




\section{VKC-39 (Basalt)}

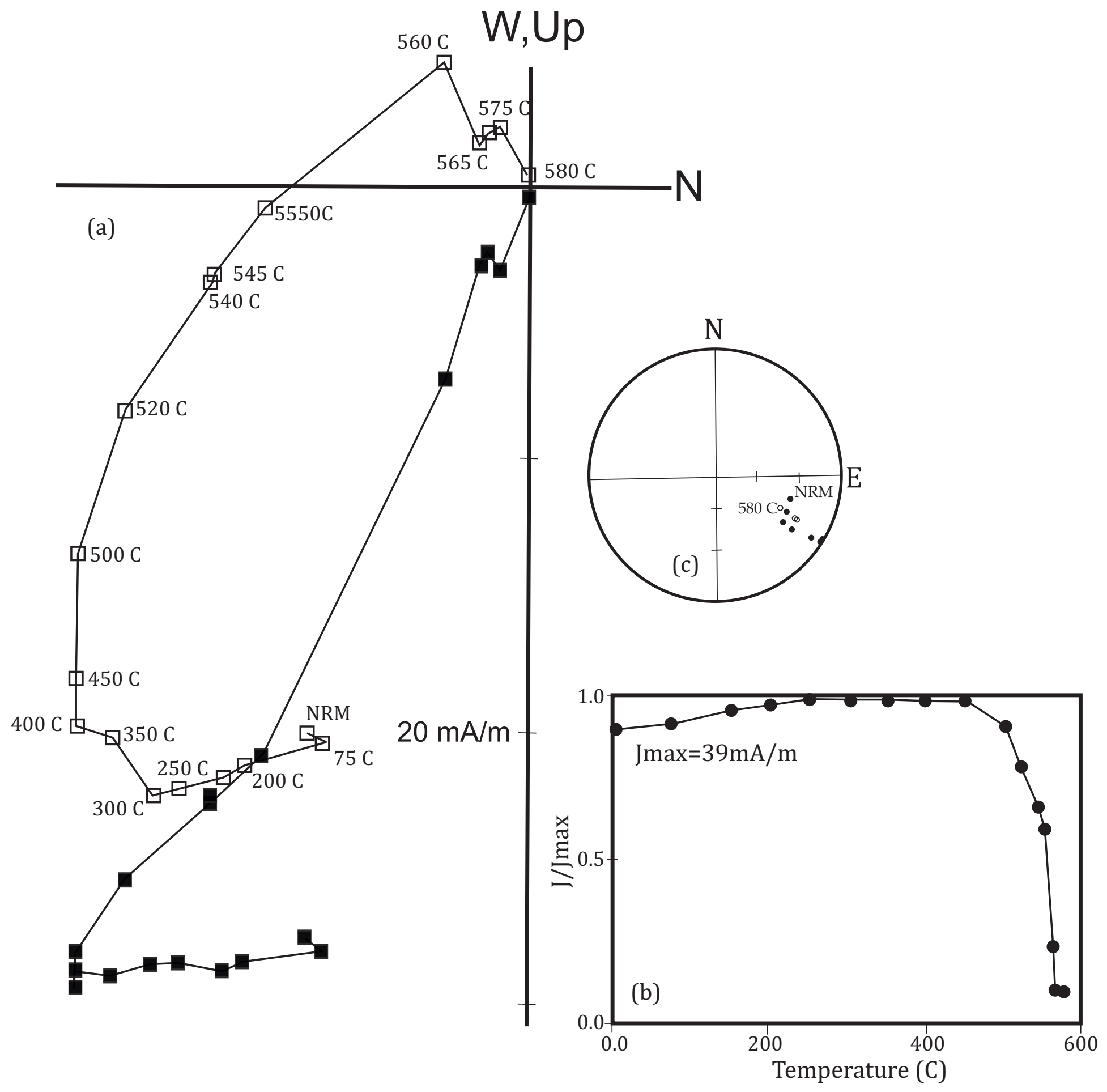




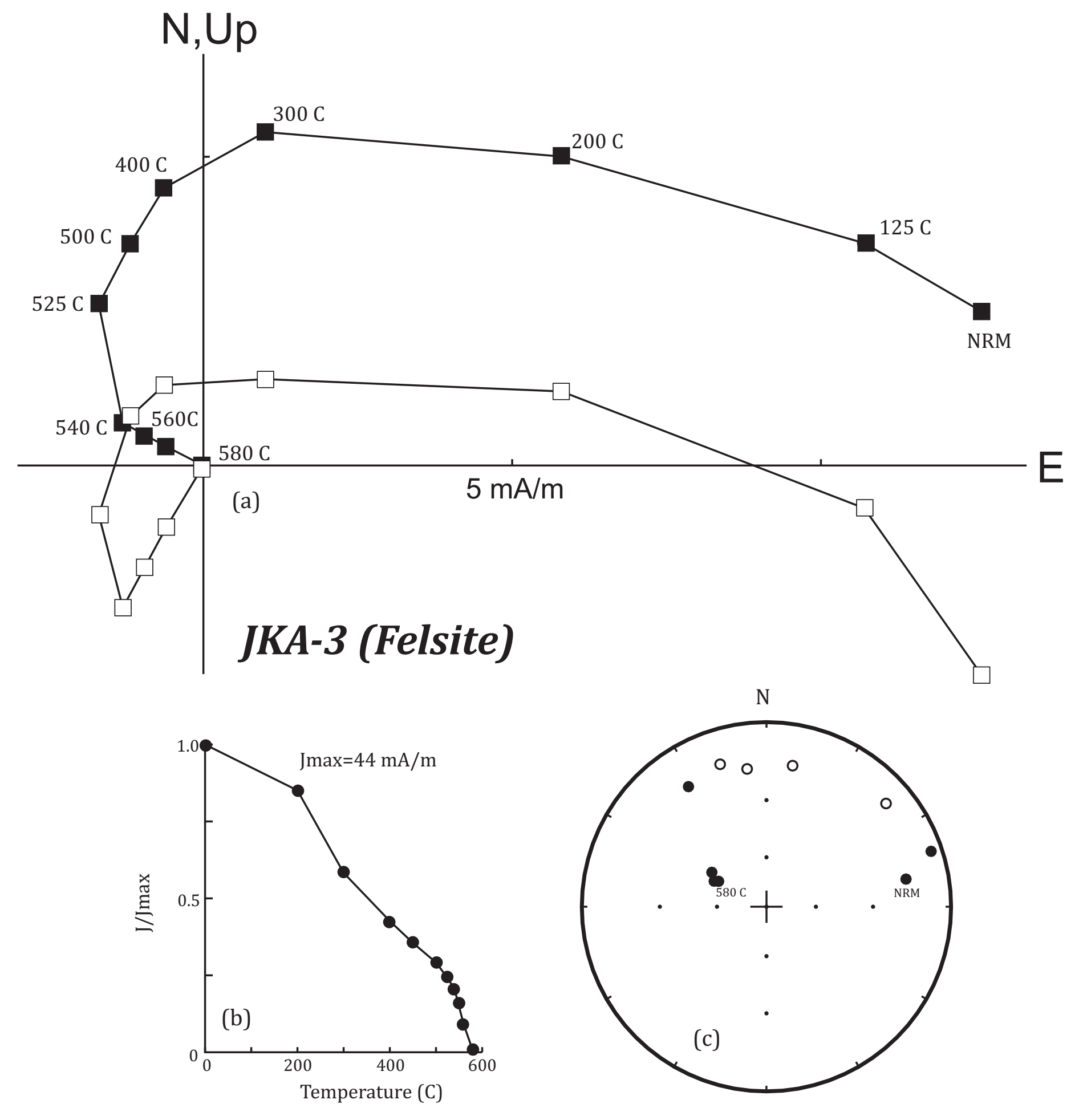

$\mathrm{N}, \mathrm{UP}$ 


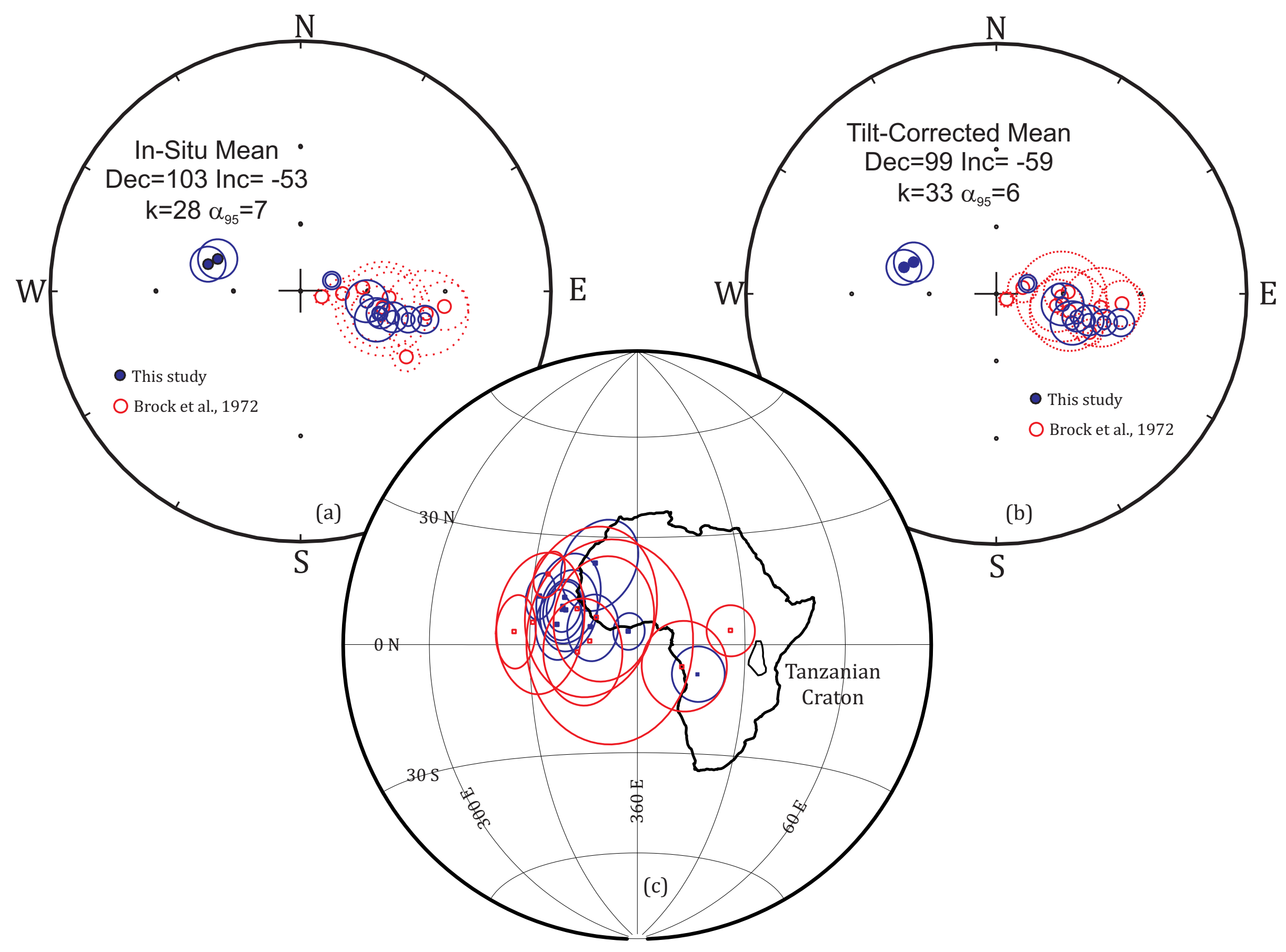




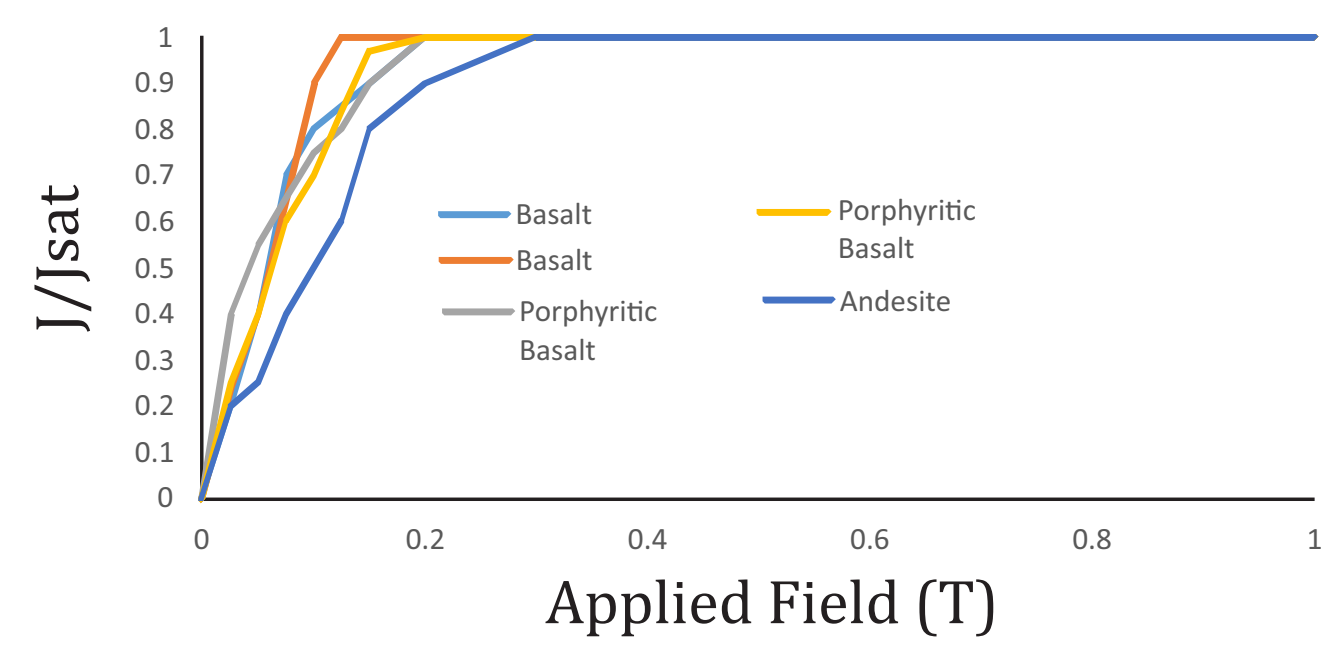


Kisii Felsite (Heating Curve)

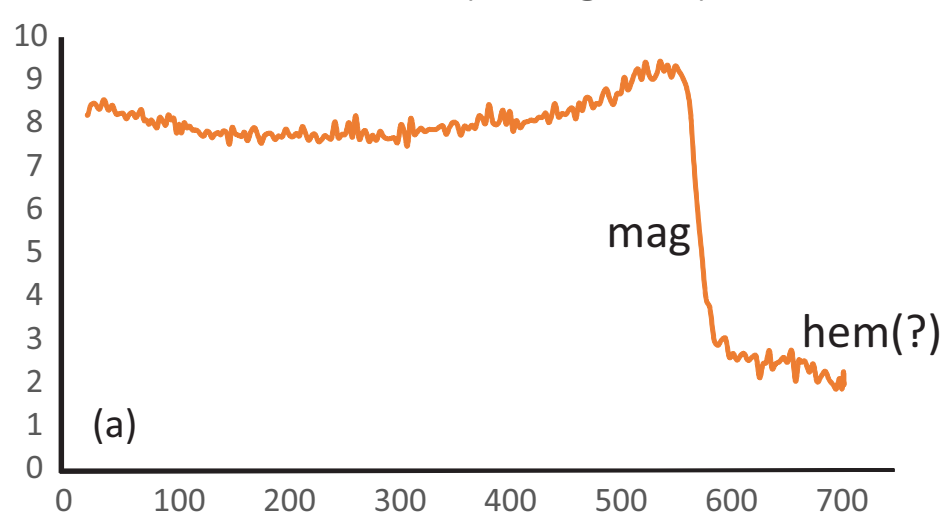

Bbp Hearing Curve

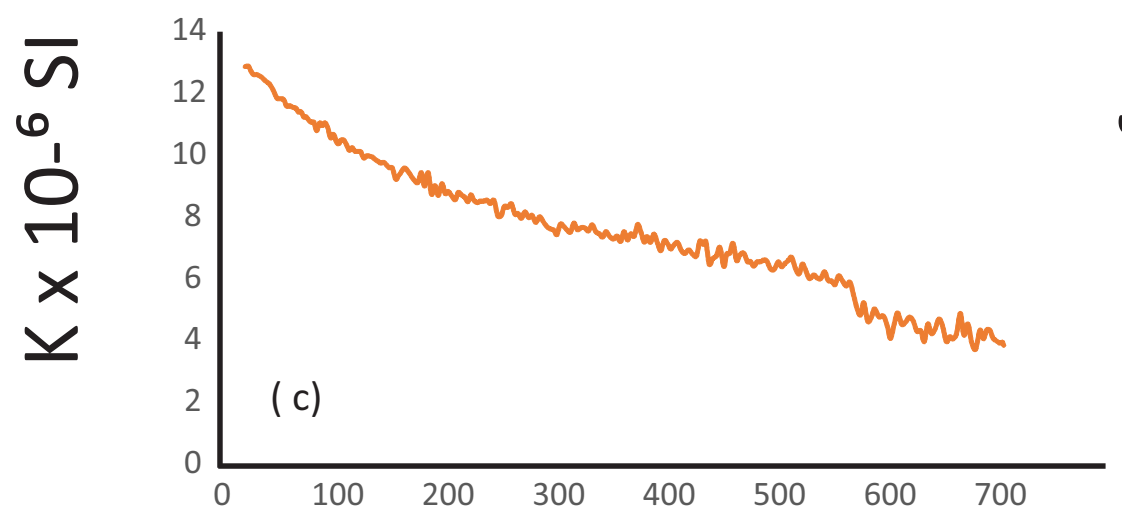

Bb Heating Curve

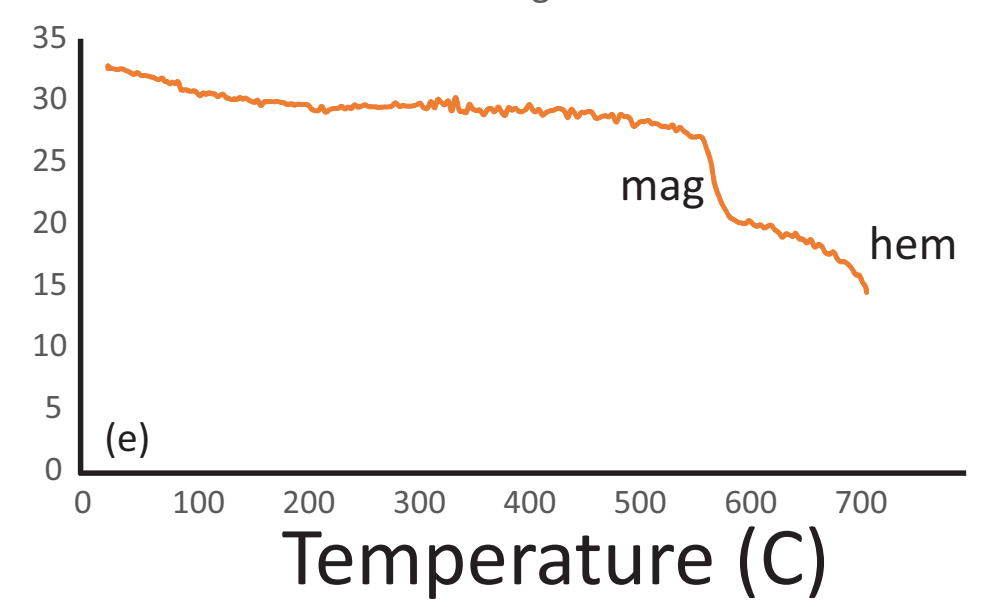

Kisii Felsite Cooling Curve

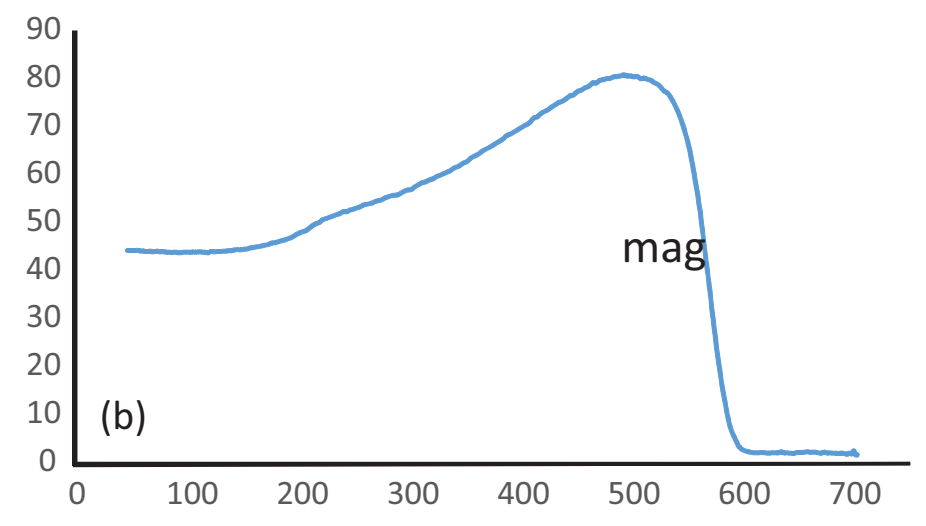

Bbp Cooling Curve
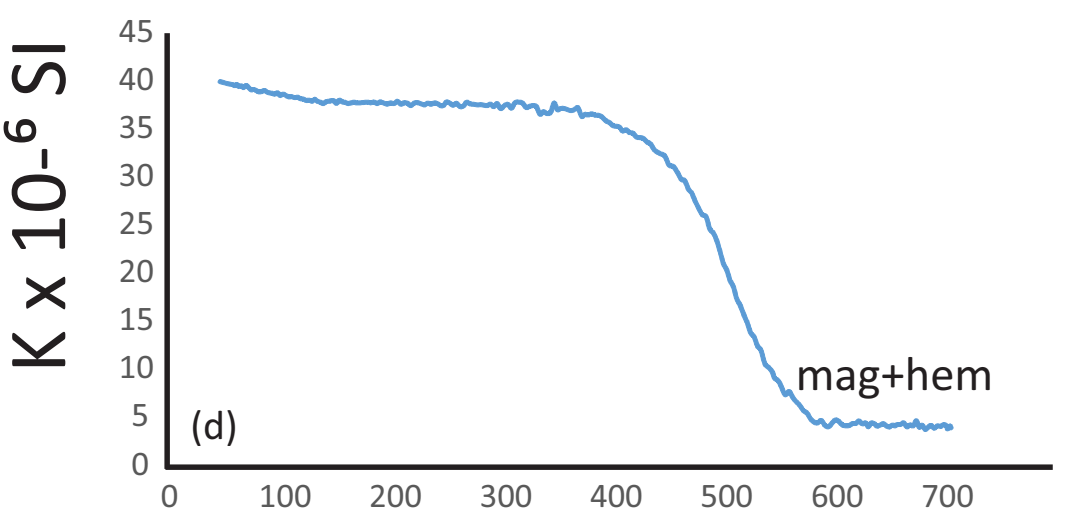

Bb Cooling Curve

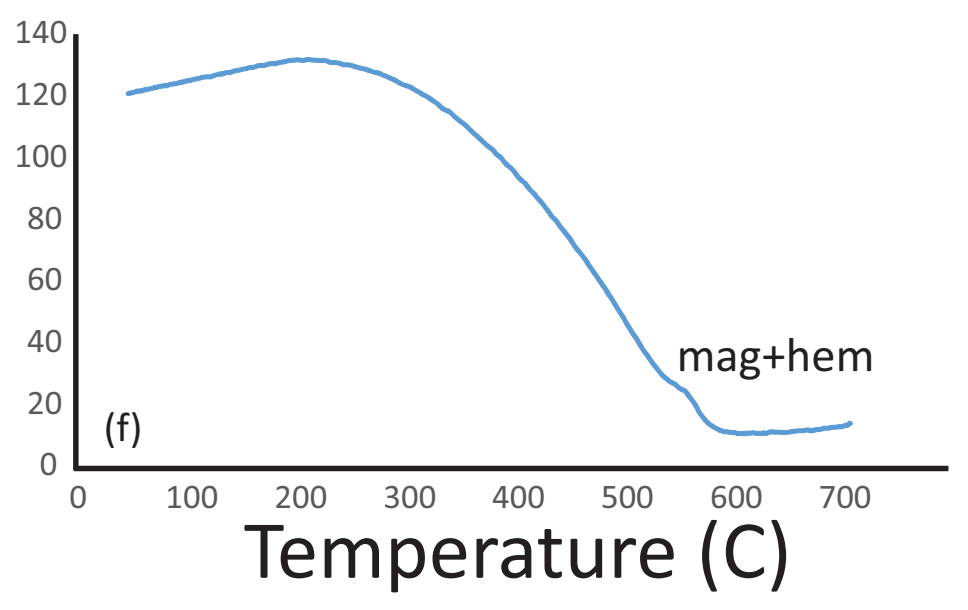




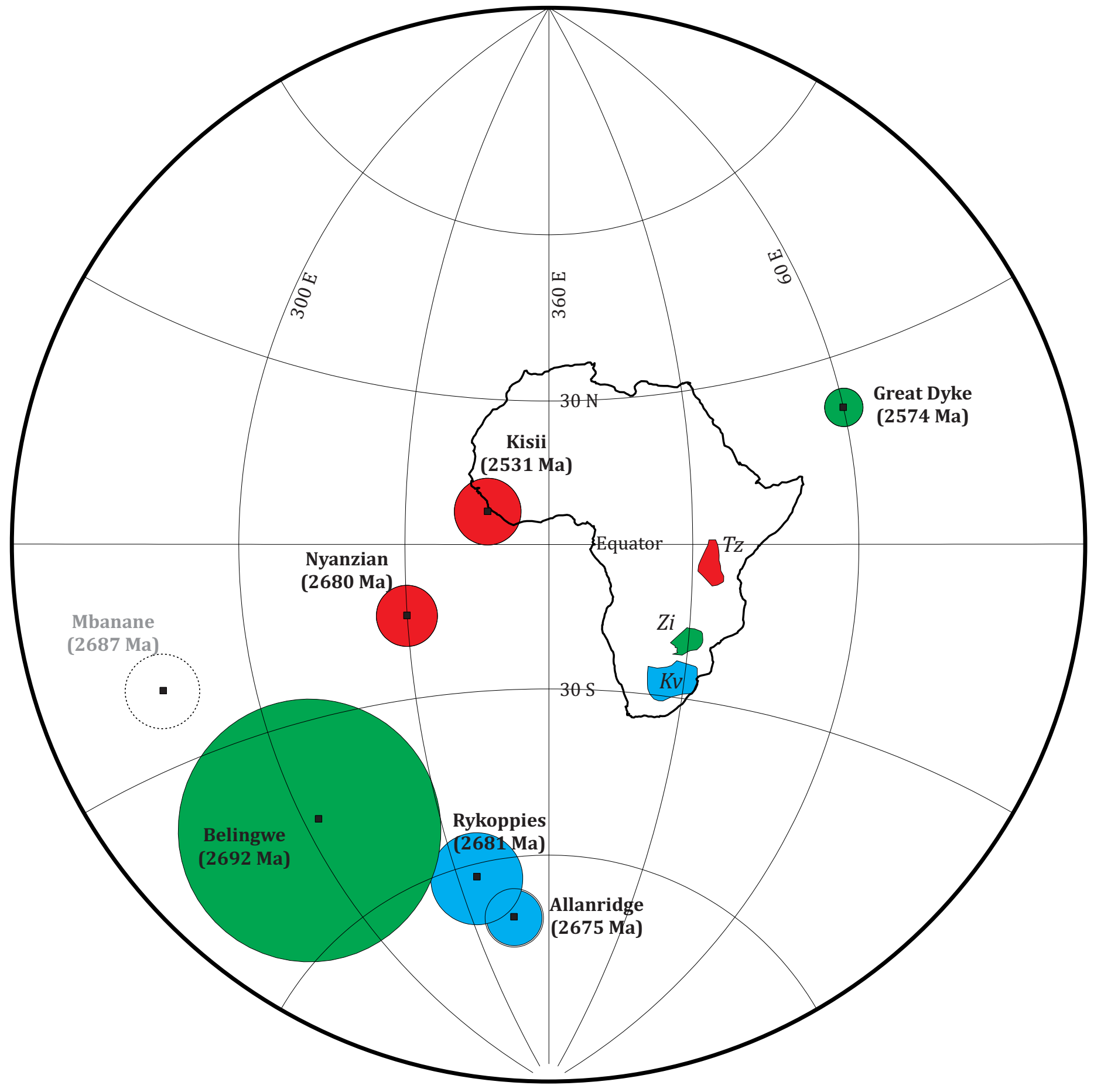



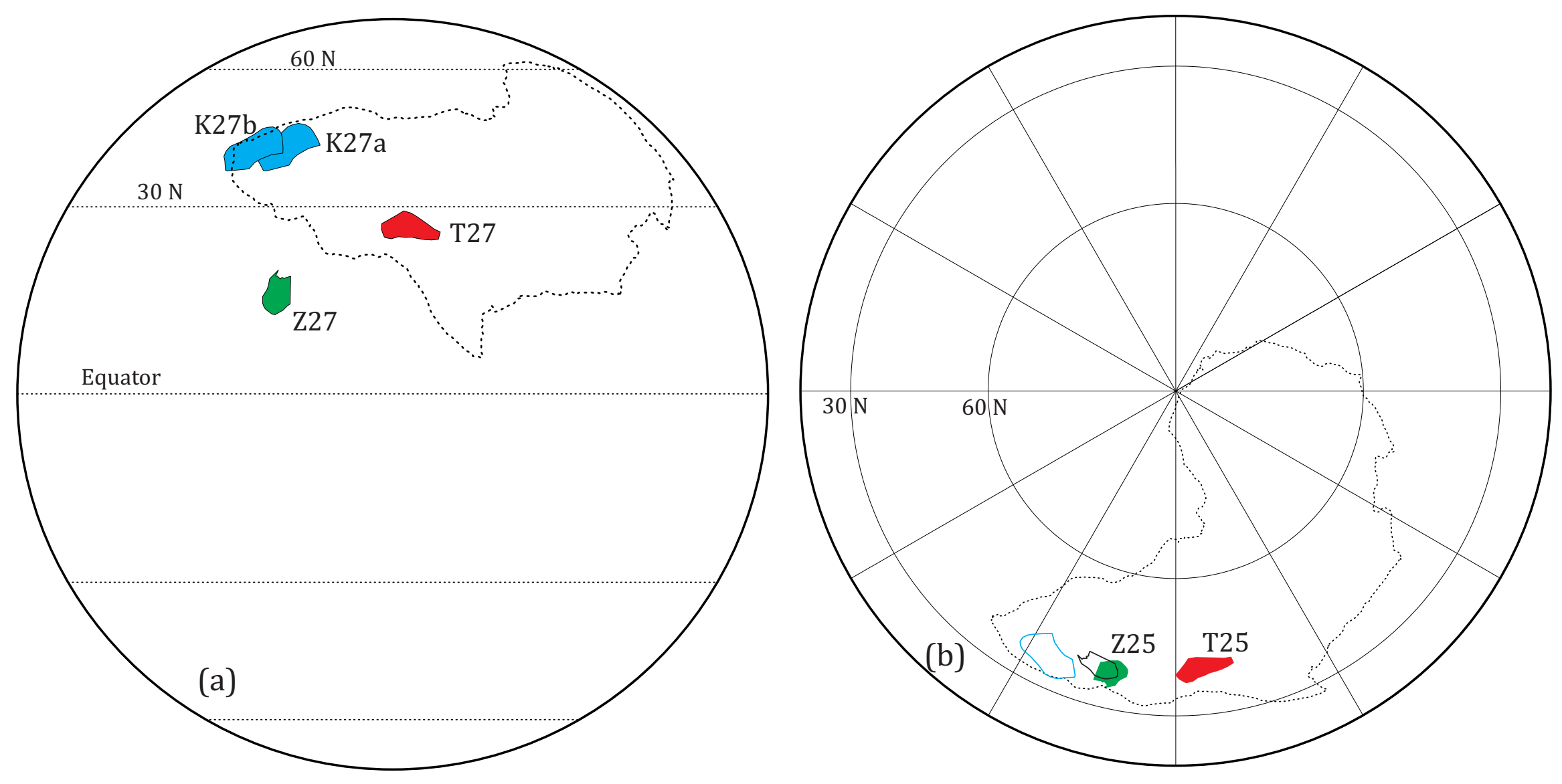


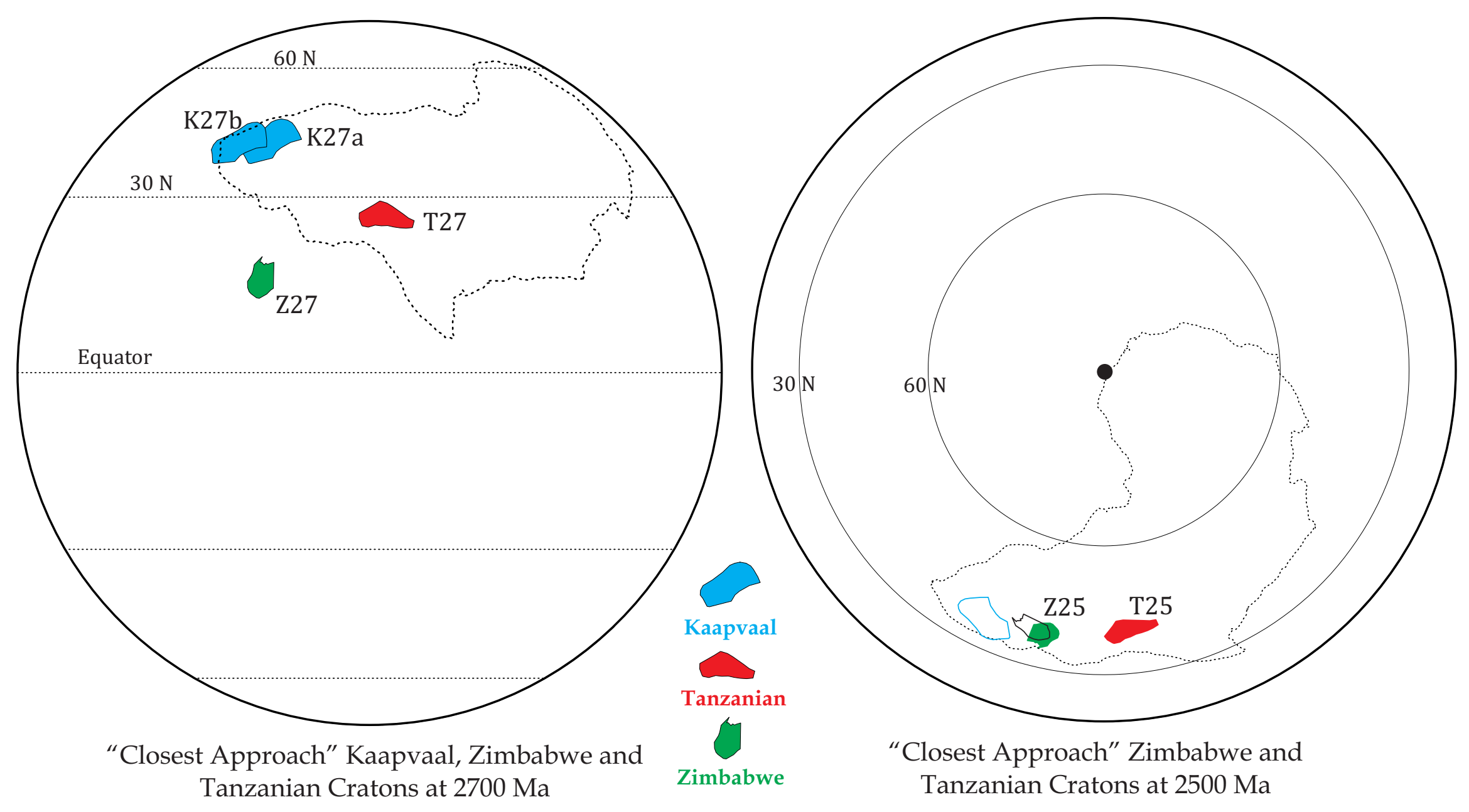

